\title{
SISTE1 promotes ABA-dependent salt stress-responsive pathways via improving ion homeostasis and ROS scavenging in tomato
}

\author{
Xiaoqing Meng ${ }^{1}$, Jing Cai ${ }^{1}$, Lei Deng ${ }^{2}, \mathrm{Ge} \mathrm{Li}^{1}$, Jian Sun ${ }^{1}$, Yonghua Han ${ }^{1}$, Tingting Dong ${ }^{1}$, \\ Yang Liu ${ }^{1}$, Tao $\mathrm{Xu}^{1}$, Siyuan $\mathrm{Liu}^{1}$, Zong-Yun $\mathrm{Li}^{1}$, and Mingku Zhu ${ }^{1}$ \\ ${ }^{1}$ Jiangsu Normal University \\ ${ }^{2}$ Chinese Academy of Sciences
}

May 5, 2020

\begin{abstract}
High salinity is one of the major limiting factors that reduces crop productivity and quality. Herein, we report that small SALT TOLERANCE ENHANCER1 (STE1) protein without any known conserved domains is required for tomato salt tolerance. Overexpression (OE) of SISTE1 enhanced the tolerance to multiple chloride salts ( $\mathrm{NaCl}, \mathrm{KCl}$ and $\mathrm{LiCl}$ ) and oxidative stress, along with elevated antioxidant enzyme activities, increased ABA and chlorophyll contents, and reduced MDA and ROS accumulations compared to that of WT plants. Moreover, decreased $\mathrm{K}+$ efflux and increased $\mathrm{H}+$ efflux were detected in the OE plants, which induced a higher $\mathrm{K}+/ \mathrm{Na}+$ ratio. In contrast, SISTE1-RNAi plants displayed decreased tolerance to salt stress. RNA-seq data revealed 1330 DEGs in the OE vs WT plants under salt stress, and the transcription of numerous and diverse genes encoding TFs, stress-related proteins, secondary metabolisms, kinases and proteins related to hormone synthesis/signalling (notably ABA and ACC), etc. was greatly elevated. Furthermore, SlSTE1-OE plants showed increased sensitivity to ABA, and the results suggest that SISTE1 promotes ABA-dependent salt stress-responsive pathways by interacting with SIPYLs and SISnRK2s. Collectively, our findings reveal that the small SISTE1 protein confers salt tolerance via ABA signalling and ROS scavenging and improves ion homeostasis in tomato.
\end{abstract}

\section{INTRODUCTION}

Among various abiotic stresses, high salinity is one of the major adverse factors that influence the geographical distribution of plants, reduce crop productivity and quality (Bartels et al. , 2005, Zhu, 2016). About 9 billion $\mathrm{hm}^{2}$ of land throughout the world are salt affected, and $20 \%$ of the arable land and $50 \%$ of irrigated land are facing salt problem (Acosta-Motos et al. , 2015, Kumar et al. , 2017). Salt stress often causes osmotic shock, ion-toxicity effects, reactive oxygen species (ROS) burst, cellular components damage in plant cells (Munns et al. , 2008). ROS are crucial signalling molecules that modulate diverse plant development and environmental stress response, the break up in ROS signalling will result in defects in these processes (Xuet al. , 2018). Therefore, ROS homeostasis must be sternly regulated by a delicate balance between ROS-producing and -scavenging enzymes. Although the facts that massive research efforts have produced a great deal of information, the accurate mechanisms underlying ROS homeostasis in plant responses to environmental stress remain unclear.

Plants response to abiotic stresses involve complex and diverse tolerance mechanisms that are activated and integrated by the transcription of thousands of genes with enormous biological functions as well as numerous genes of unknown roles (Kant et al. , 2007). These genes encode proteins involved in signal sensing and regulatory pathways or the proteins conferring stress tolerance or enzymes present in pathways resulting in structural metabolites and osmolytes biosynthesis (Apse et al. , 2002, Seki et al. , 2003, Zhu, 2016). Presently, substantial amount of data has been made in identifying and characterizing the components of 
stress signalling networks. For example, the first established plant abiotic stress signalling pathway, the SOS pathway, is a calcium-dependent protein kinase pathway that plants use for salt stress signalling and $\mathrm{Na}^{+}$ tolerance (Zhu, 2002, Zhu, 2016). To resist $\mathrm{Na}^{+}$toxicity, plants often limit $\mathrm{Na}^{+}$accumulations in cytoplasms via reducing $\mathrm{Na}^{+}$uptake, increasing $\mathrm{Na}^{+}$efflux back to soil or sequestrating $\mathrm{Na}^{+}$into vacuoles. Therefore, efficient control of cellular ion homeostasis has been widely recognized as one of the major components of plant salinity tolerance (Munns et al. , 2008, Yu et al. , 2015).

The phytohormone ABA mediates diverse and critical physiological responses in response to multiple environmental stresses, such as salt, osmotic and cold stresses (Fernandoet al. , 2016). Salt stress commonly triggers the accumulation of cellular ABA, which in turn elicits many adaptive stress responses in plants (Bartels et al. , 2005, Lee et al. , 2012, Zhu, 2002). The fact that the expression of ABA-responsive genes plays a vital role in enhancing salt tolerance has been widely characterized (Huanget al. , 2018, Kumar et al. , 2017, Zhu, 2016). Actually, there are convincing evidences that ROS are also critical second messengers in ABA signalling pathways in plant guard cells (Xu et al. , 2018). Furthermore, characterizations of ABA-sensitive or ABA-insensitive Arabidopsismutants-in which ABA-related genes are upregulated or downregulated-have identified multiple components of ABA signalling (Ma et al. , 2009, Park et al. , 2009, Umezawa et al. , 2009). Recent work has shown that the binding of ABA to PYR/PYL/RCAR (hereafter referred to as PYL) receptor family induces the interaction between PYLs and PP2Cs, which in turn inhibits the activity of downstream factors PP2Cs and thus relieve SnRK2s to activate downstream effectors cause the response to ABA (Fujii et al. , 2009).

Tomato is one of the most important vegetable and horticultural crops due to its worldwide consumption. Moreover, tomato is also employed as an excellent model for genetic studies (Aliet al. , 2014). Nevertheless, most tomato cultivars are moderately sensitive to salt at all stages of development, including seed germination, vegetative growth and reproduction (Foolad, 2004). Presently, although many progresses have been made to characterize the genetic regulation of salt tolerance in tomato, the specific biological, biochemical and molecular roles of most tomato genes are still unclear. Previously, in order to identify novel ripeningrelated ethylene-dependent components, interacting protein 7 (Sl;INT7) was isolated via a yeast two-hybrid screening using the $N R$ (Never ripe) as bait (Aboul-Soud et al. , 2009). Sl;INT7 was a small protein composed of 77 aa that shared no any known conserved domains, and its expression could be induced by SA, ABA, JA and salt (Aboul-Soud et al. , 2009). In the present study, we found that Sl;INT7 could not interact with the 6 ethylene receptor proteins SlETR1-6 (including NR, namely SlETR3), indicating that the previous interaction was a false positive. Herein, we reported that Sl;INT7 played a role in tomato salt tolerance, hence it was renamed $S$ ALT $T$ OLERANCE $E$ NHANCER1 (STE1), and our findings suggest that SISTE1 confers salt tolerance via ABA signalling and ROS scavenging and improves ion homeostasis in tomato.

\section{MATERIALS AND METHODS}

\section{Plant materials and abiotic stress/hormone treatments}

Seeds of the WT tomato (Solanum lycopersicom Mill. cv. Ailsa Craig) and both transgenic plants (T4 generation) were sterilized before germinating, and the seedlings were then sown in commercially sterilized soil mix (peat moss, perlite, and vermiculite, $3: 1: 1, \mathrm{v} / \mathrm{v} / \mathrm{v}$ ). The plants were cultivated in a greenhouse under sodium lights with $16 \mathrm{~h}$ days $(27 \mathrm{degC})$ and $8 \mathrm{~h}$ nights $(18 \mathrm{deg} \mathrm{C})$, and irrigated with a $1 \mathrm{~g} \mathrm{~L}^{-1} \mathrm{MS}$ nutrient solution once per week.

Abiotic stress and hormone treatments were carried out using potted 35 day-old plants chosen based on their uniformity. Salt and dehydration stresses were carried out by submerging the tomato roots in $200 \mathrm{mM}$ $\mathrm{NaCl}$ and 20\% PEG6000, respectively, then leaves and roots were harvested. For hormone treatments, the plants were sprayed with $100 \mu \mathrm{M} \mathrm{ABA}$ and ACC solutions, then the leaves were collected. Untreated plants were used as controls, and three independent experiments were performed. All the samples were frozen immediately in liquid nitrogen and stored at $-80{ }^{\circ} \mathrm{C}$. 


\section{RNA extraction and qRT-PCR analysis}

Total RNA was extracted using Trizol reagent (Invitrogen, Shanghai, China). $1 \mu \mathrm{g}$ RNA was reversetranscribed into cDNAs using PrimeScript reverse transcriptase (with gDNA Eraser) (TaKaRa, Dalian, China) with the mix of Oligo dT Primer and Random 6 mers. qRT-PCR analysis were performed as described previously using the CFX96 Real-Time System (Bio-Rad, USA) (Zhu et al. , 2018). The tomato EФ1a gene were selected as internal standard for abiotic stress analysis (Løvdal et al. , 2009). The mean Ct values of each gene were obtained from three independent experiments.

\section{Construction of RNAi and overexpression vectors and tomato transformation}

The coding region of SISTE1 was cloned into the pBI121 binary vector, and the SISTE1 -RNAi vector was constructed using the pBIN19 binary vector, both vectors were driven by the CaMV 35S promoter, then two constructs were transformed into Agrobacterium tumefaciens (LBA4404). To generate transgenic tomato (Ailsa Craig) plants, Agrobacterium-mediated transformation of cotyledon was performed, and transformed plants were selected for kanamycin resistance $\left(50 \mathrm{mg} \mathrm{L}^{-1}\right)$. The positive transgene was detected using the primers SISTE1 -Q-F/R and NPTII -F/R. The specific primers for vector construction and detection are listed in Table S1.

\section{Phenotype analyses for ABA and ACC sensitivity, oxidative stress, $\mathrm{NaCl}, \mathrm{KCl}$ and $\mathrm{LiCl}$ stress tolerance of transgenic seedlings}

For all the phenotype analyses of the plants at the post-germination stage, tomato seeds were sterilized and germinated, then the seeds of consistent germination were selected and transferred to the control 1/2 MS medium and the medium containing $\mathrm{NaCl}(120$ and $160 \mathrm{mM}), \mathrm{KCl}(100$ and $120 \mathrm{mM}), \mathrm{LiCl}(6$ and $9 \mathrm{mM})$, MV $(5$ and $10 \mu \mathrm{M})$, ABA $(3$ and $6 \mu \mathrm{M})$ and ACC $(10 \mu \mathrm{M})$. Cylindrical culture vessels $(9.5 \times 10 \mathrm{~cm}$, diameter $\times$ height) containing the seedlings were incubated in a growth chamber for $10 \mathrm{~d}$. Then the shoot and root lengths of each seedling (n [?] 30) of the WT and transgenic lines were measured. For the expression analysis after ABA treatment, the 25-day-old WT and transgenic plants of similar size were sprayed with $100 \mu \mathrm{M}$ $\mathrm{ABA}$ and left for $4 \mathrm{~h}$ in a greenhouse, untreated plants were used as controls. The gene-specific primers are listed in Table S1.

\section{Evaluation of salt stress tolerance}

For salt stress in the soil, the WT and transgenic plants were pre-grown in seedling nurseries for $15 \mathrm{~d}$ and transferred to pots in a greenhouse. Then 8-week-old plants of similar size were selected for the salt tolerance assays. The plants were irrigated with a $300 \mathrm{mM} \mathrm{NaCl}$ solution $(200 \mathrm{~mL})$ every $3 \mathrm{~d}$ from the bottom of the pots. Pictures were taken to record the phenotypes. The upper leaves in the same positions of the WT and transgenic plants were used for the determination of stress-related physiological indicators. ABA measurement was carried out using high-performance liquid chromatography (HPLC, Rigol L3000) according to the method described before (Zhanget al. , 2012). The protocol for the determination of chlorophyll content was as published previously using the thermo solution 220 spectrophotometer (Zhu et al. , 2015). MDA content, and CAT and SOD activities were detected using the corresponding test kits (for plant) purchased from Nanjing Jiancheng Bioengineering Institute (Nanjing, China) according to the manufacturer's protocols. $\mathrm{H}_{2} \mathrm{O}_{2}$ was histochemically detected using the DAB staining according to the procedure described by Hu et al.(2013).

\section{Measurement of $\mathrm{K}^{+}$and $\mathrm{Na}^{+}$and visualization of $\mathrm{Na}^{+}$distribution}

WT and transgenic plants were cultivated in quarter-strength Hoagland nutrition solution which was replaced every $72 \mathrm{~h}$. Then uniform 25-day-old WT and transgenic plants were subjected to $100 \mathrm{mM} \mathrm{NaCl}$ stress for 7 
days. The plants were washed with deionized water, dried at $70{ }^{\circ} \mathrm{C}$ and ground to power. $0.25 \mathrm{~g}$ of each root sample was digested in a $\mathrm{H}_{2} \mathrm{SO}_{4}-\mathrm{H}_{2} \mathrm{O}_{2}$ solution, then the extracts were used to determine the $\mathrm{K}^{+}$and $\mathrm{Na}^{+}$ contents according to our previous publication using an atomic absorption spectrophotometer (Shimadzu AA-680, Kyoto, Japan) (Yuet al. , 2015). At the same time, the roots were collected after $24 \mathrm{~h}$ of $\mathrm{NaCl}$ stress to detect the expression of ion homeostasis-related genes. The gene-specific primers are listed in Table S1.

The visualization of $\mathrm{Na}^{+}$in tomato roots was conducted as described previously with small modification (Yi et al. , 2015). Briefly, the WT and transgenic plants were cultivated in the same conditions described above, then the plants were treated with $100 \mathrm{mM} \mathrm{NaCl}$ for $3 \mathrm{~d}$, after which, the roots were stained with $20 \mu \mathrm{M}$ CoroNa Green-AM (Invitrogen) in the presence of $0.02 \%$ pluronic acid (Invitrogen) in the dark condition for $5 \mathrm{~h}$. Then the root tips were washed with $200 \mathrm{mM}$ PBS ( $\mathrm{pH}$ 7.4) six times to remove excess dye and examined using a microscope (Olympus IX71S8F-3, Japan). All the observations were repeated at least ten roots for each line.

\section{Transient ion fluxes measurements of $\mathrm{K}^{+}$and $\mathrm{H}^{+}$}

Net fluxes of $\mathrm{H}^{+}$and $\mathrm{K}^{+}$were detected using a NMT (Non-invasive micro-test technique) system (NMT100-SIM-YG, Younger USA LLC, USA), as described in our previous publications (Sun et al. , 2009, Yu et al. , 2015). The WT and transgenic plants were cultivated in quarter-strength Hoagland nutrition solution, then uniform 25-day-old plants were selected. The fluxes of $\mathrm{H}^{+}$and $\mathrm{K}^{+}$were recorded for 6 min before salt shock $(100 \mathrm{mM} \mathrm{NaCl})$ was added. Afterwards, transient ion fluxes were determined for another $20 \mathrm{~min}$ in the apex region (approximately $500 \mu \mathrm{m}$ from the root tips). Transient ion fluxes were expressed as the mean of at least six measuring data.

\section{RNA sequencing and data analysis}

For the tomato RNA-seq analysis, the 8-week-old WT and SISTE1 - overexpressing plants (lines 1 and 6) were irrigated with water containing $300 \mathrm{mM} \mathrm{NaCl}$ from the bottoms of the pots, then the roots (mixed samples of six plants of each line with two biological repeats) were collected after $24 \mathrm{~h}$. Afterwards $1.5 \mu \mathrm{g}$ RNA of per sample was employed for the generation of sequencing libraries and sequenced using Illumina HiSeq 2500 platform by Novogene Co., LTD (Beijing, China) as described in our previous publication (Meng et al. , 2019). Gene functions were annotated based on tomato reference genome and $\mathrm{Nr}$ databases. To identify DEGs, genes with an adjusted $\log _{2} \mathrm{FC}>0.5$ and padj $<0.05$ found by DESeq were assigned as DEGs (Anders et al. , 2010). qRT-PCR was carried out to validate the results of RNA-seq, the gene-specific primers of stress-related genes are listed in Table S1. RNA-Seq data are available in the NCBI database under accession numbers: WT-1, SRR8184599; WT-2, SRR8184598; OE1-1, SRR8184593; OE1-2, SRR8184592; OE6-1, SRR8184595; OE6-2, SRR8184594.

\section{Firefly luciferase complementation imaging}

To generate the constructs for split luciferase assay, the coding sequences of each gene was amplified and cloned into the pDONR207 ENTRY vector using BP clonase II (Invitrogen). SlSTE1 gene was recombined into the pEarley-nLUC vector, 6 SlETRs , 12SlPYLs , 8 SlSnRK2s and 7 SlPP2Cs were recombined into the pEarley-cLUC vector using an LR reaction (Invitrogen). Agrobacterium strains (GV3101) harbouring the indicated constructs were grown and resuspended in $10 \mathrm{mM}$ MES, pH 5.6, $10 \mathrm{mM} \mathrm{MgCl} \mathrm{M}_{2}$ and $100 \mu \mathrm{M}$ acetosyringone with a final concentration of $\mathrm{OD}_{600}=0.5$ (Chen et al. , 2008). Before co-transformation into $N$. benthamianaleaves, the strains were incubated at $28{ }^{\circ} \mathrm{C}$ for $2 \mathrm{~h}$ and then expressed for $48 \mathrm{~h}$. The luciferase activity was detected using a CCD camera (Princeton instruments, Trenton, NJ, USA). Each interaction had at least three biological replicates. The primers used for related plasmid constructions were shown in Table S2. 


\section{Bimolecular fluorescence complementation}

The coding sequences of SlSTE1 and SlPYL5,SlSnRk2.1, SlSnRk2.2 genes were amplified, and the products were fused downstream of the N-terminal half of EYFP in pSAT6-nEYFP-C1 and the C-terminal half of EYFP in pSAT6-cEYFP-C1, respectively. For microbombardment assays, different combinations of plasmids encoding nEYFP and cEYFP fusion proteins were mixed at a 1:1 ratio (500 ng each), and were used for particle bombardment to coexpress in onion epidermal cells according to the method described before (Citovsky et al. , 2006). The epidermal cells were observed for fluorescence under confocal laser scanning microscope model A1 (Nikon, Japan). The primers used for related plasmid constructions were shown in Table S1.

\section{Statistical analysis}

When appropriate, the results were analyzed by one-way analysis of variance (ANOVA) and means different were significant by a Dunnett's test at $\mathrm{P}<0.05$ and $\mathrm{P}<0.01$. Statistical analyses were conducted with SPSS software 20 version (IBM Corp., USA).

\section{RESULTS}

\section{SISTE1 expression was significantly induced by various stress and hormone treatments}

SISTE1 is a small protein composed of 77 aa, bioinformatics analysis shows that it does not have any known conserved domains, while its protein sequence is highly similar to homologous proteins in Solanaceae family plants, e.g., 100\%, 98.7\% and 96.1\% sequence similarity to the protein in Solanum tuberosum, Solanum pennellii andCapsicum annuum, respectively (Fig. S1). To validate whetherSlSTE1 is involved in stress response, SISTE1 transcription was detected under stress treatments. SISTE1 expression was remarkably upregulated after salt treatment and peaked at $1 \mathrm{~h}$ in roots before decreasing, while it was less affected by salt in leaves. Similarly, the increased transcription of SISTE1 was also mainly detected in roots upon dehydration. In addition, SlSTE1 mRNA was also induced after ABA and ACC treatments (Fig. S2A-C). The results led us to examine the promoter region of SISTE1 ( $1.5 \mathrm{~kb}$ upstream from the ATG site). Multiple stress response- and hormone-related elements were found, such as ABRE (ABA-responsive element), MBS (MYB recognition site), TCA (SA-responsive element) and TGACG-motif (MeJA-responsive element) (Fig. S2D). This result, combined with the stress-induced expression of SISTE1, suggested thatSlSTE1 plays a role in the tomato stress response.

\section{SISTE1 cannot interact with ethylene receptors}

To explore the physiological roles of the SISTE1 gene in depth, 5SISTE1 -overexpressing (OE) and 11 SISTE1 -RNAi (Ri) independently transformed lines were obtained. Three overexpressing lines (OE-1, -2 and -6, 20-54-fold overexpression) and three RNAi lines (Ri-4, -5 and -6, 90.4-93.4\% silence) with greatly upor down-regulated SISTE1 expression, respectively, were selected for further analysis (Fig. 1A and F). The results showed that both overexpression and silence of SISTE1 had no obvious effect on tomato fruit ripening (data not shown). Then the interaction between SISTE1 and NR (SlETR3) was further verified by Yeast Two-Hybrid, while no interaction was observed, and SISTE1 could also not interact with other five ethylene receptors, including SIETR1-2 and SIETR4-6 (Fig. S3A and B). The results might be due to the fact that SISTE1 is predominantly localized on the PM, thus the present yeast two-hybrid system used may not be suitable for analyzing the interaction between these proteins. Therefore, the split luciferase complementation imaging (LCI) was further applied, while also no interaction was observed (Fig. S3C and D), indicating that the previous interaction between SISTE1 and NR suggested by yeast two-hybrid screening was a false positive (Aboul-Soud et al. , 2009). Collectively, the data suggested that SISTE1 could not interact with all ethylene receptors in tomato. 


\section{Performance of transgenic SISTE1 plants under $\mathrm{NaCl}, \mathrm{KCl}$ and $\mathrm{LiCl}$ stresses}

SISTE1 expression was induced by $\mathrm{NaCl}$ and ABA treatments, which prompted us to further test the correlation between SISTE1 and salt tolerance. First, the salt tolerance of the OE and Ri lines was examined at the post-germination stage. The growth of seedlings from both transgenic lines was similar to that of the WT plants on the control medium. On the medium containing $\mathrm{NaCl}$, the overexpression and RNAi of SISTE1 resulted in opposite phenotypes, although no noticeable difference in shoot lengths was detected (Fig. 1B-E and G-J). The root length of Ri lines was obviously shorter than that of the WT plants (Fig. $1 \mathrm{C}$ and $\mathrm{E}$ ), and some Ri plants could not even grow roots or had only grown short main roots under 160 $\mathrm{mM} \mathrm{NaCl}$ (Fig. 1C). However, the OE plants grew better than the WT plants. The root length of OE lines was longer than that of the WT plants (Fig. 1H and J). The results revealed that SISTE1 conferred salt tolerance during the post-germination stage in tomato.

Moreover, to test whether the salt sensitivity of the transgenic plants was specific to certain salts, the salt tolerance of the $\mathrm{OE}$ plants was further examined under $\mathrm{LiCl}$ and $\mathrm{KCl}$ stresses. Interestingly, theSlSTE1 - $\mathrm{OE}$ seedlings also exhibited enhanced $\mathrm{LiCl}$ and $\mathrm{KCl}$ tolerance (Fig. 2A-H). The longer roots and shoots of $\mathrm{OE}$ lines than those in the WT seedlings grown on $\mathrm{LiCl}$ medium suggested that the $\mathrm{OE}$ plants were less hypersensitive to $\mathrm{Li}^{+}$, a more toxic analogue of $\mathrm{Na}^{+}$, which can be applied at a low concentration without causing serious osmotic stress (Fig. 2E and F). These results suggested that the SISTE1 -OE plants performed better under stress from different types of salt such as $\mathrm{NaCl}, \mathrm{KCl}$ and $\mathrm{LiCl}$, than the WT plants; thus, the SISTE1 salt response is not specific to sodium.

\section{Performance of transgenic SlSTE1 plants under salt stress in soil}

To further investigate the performance of transgenic plants under $\mathrm{NaCl}$ stress in the soil, 8-week-old WT, $\mathrm{OE}$ and Ri plants were irrigated with $300 \mathrm{mM} \mathrm{NaCl}(200 \mathrm{~mL})$ every $72 \mathrm{~h}$. Under control conditions, normal morphological phenotypes were observed in the OE and Ri plants, while they presented the opposite phenotype when treated with salt stress (Fig. $3 \mathrm{~A}-\mathrm{F}$, upper and lower panels). The Ri plants showed slightly more severe and faster $\mathrm{NaCl}$-induced damage during the salt assay than the WT plants. For instance, the chlorosis and wilting of leaves in the Ri plants were slightly more severe than WT leaves (Fig. 3 B-C). However, the OE plants displayed delayed wilting and necrosis, and most upper leaves remained vigorous at $15 \mathrm{~d}$ post-treatment (Fig. 3E). After $25 \mathrm{~d}$, the salt hypersensitivity of Ri plants was severe, and some were dead (Fig. 3C), while some upper leaves of the OE plants remained green (Fig. 3F). After re-watering for $5 \mathrm{~d}, 59-70 \%$ of the OE plants survived, and $32-37 \%$ of the Ri plants survived, which were higher and lower than the survival rates of the WT plants (41\%), respectively (Fig. 3G). Hence,SlSTE1 confers enhanced tolerance to $\mathrm{NaCl}$ stress in the soil.

To characterize the salt tolerance of the transgenic plants, several typical stress-related physiological parameters were determined. No distinct differences in these parameters were detected among the WT and transgenic plants under normal conditions, except lower CAT activity was detected in the Ri plants than that in WT plants (Fig. 3H-L). Upon exposure to salt stress, the ABA content in the OE lines was markedly higher than that of WT after $15 \mathrm{~d}$ of salt stress (Fig. 3H). Furthermore, slight reductions in the activities of ROS-scavenging enzymes CAT and SOD and chlorophyll content were detected in Ri leaves compared with that of WT plants, while the levels of these three parameters were significantly higher in plants from at least one OE line than those in the WT plants (Fig. 3I-K). In addition, OE lines accumulated less MDA than the WT plants, and this was accompanied by an increase in MDA content in Ri lines (Fig. 3L). These results demonstrated that the different survival rates under salt stress of the transgenic lines were associated with the corresponding physiological parameters, and the expression of SISTE1 was correlated with the degree of salt tolerance in transgenic tomato plants.

\section{$S l S T E 1$ plays a role in $\mathrm{Na}^{+}$and $\mathrm{K}^{+}$homeostasis}

To further characterize the salt tolerance of SISTE1 -OE plants, visualization of $\mathrm{Na}^{+}$accumulation in root tips was carried out in WT and OE plants exposed to $\mathrm{NaCl}$ stress using CoroNa Green, the emission of which 
increases upon $\mathrm{Na}^{+}$binding (Yi et al. , 2015). Fluorescence was barely observed in the root tips of the WT and OE plants under normal conditions, whereas less fluorescence was detected in the OE plants compared with that of WT plants after $3 \mathrm{~d}$ of $\mathrm{NaCl}$ stress (Fig. 4A). Non-invasive micro-test technique (NMT) data revealed that $\mathrm{NaCl}$ shock induced a remarkable increase in $\mathrm{K}^{+}$and $\mathrm{H}^{+}$efflux in the root apex of the WT and $\mathrm{OE}$ plants, whereas the OE plants exhibited significantly lower $\mathrm{K}^{+}$and higher $\mathrm{H}^{+}$efflux than the WT plants (Fig. 4B-D). As a result, ion content analysis revealed that the $\mathrm{K}^{+} / \mathrm{Na}^{+}$ratios were higher in $\mathrm{OE}$ plants than in WT plants after $7 \mathrm{~d}$ of salt stress (Fig. 4E). Moreover, the expression of almost all detected genes involved in ion homeostasis, including LKT $\left(\mathrm{K}^{+}\right.$uptake channel), NHX $\left(\mathrm{Na}^{+} / \mathrm{H}^{+}\right.$exchanger), LHA (PM H ${ }^{+}$-ATPase), SOS1 $\left(\mathrm{Na}^{+} / \mathrm{H}^{+}\right.$antiporter) and SOS2 (serine/threonine protein kinase), was upregulated (most were upregulated 2-3.5-fold) in OE plants compared to that in WT plants under control conditions. Under $\mathrm{NaCl}$ stress, the expression of most of these genes was also higher in plants from at least one OE line than in WT plants (Fig. 4F). The results suggested that SlSTE1 may modulate the transcription of ion channel/transporter genes under $\mathrm{NaCl}$ stress to maintain ion homeostasis, thus improving the salt tolerance of the OE tomato plants.

\section{SISTE1-OE plants accumulate less ROS and are less sensitive to oxidative stress}

Salt stress can enhance ROS production and cause secondary oxidative stress effects (Zhu, 2016). Thus, the possible roles of SISTE1 in maintaining ROS homeostasis were evaluated. $\mathrm{H}_{2} \mathrm{O}_{2}$ and $\mathrm{O}^{-2}$ are two main ROS that participate in stress signalling. Consequently, oxidative burst was detected by the ROS-reactive dye diaminobenzidine (DAB) using detached leaves. Without salt stress, the OE, Ri and WT plants displayed similar basal levels of ROS. After exposure to salt stress for $15 \mathrm{~d}$, the OE plants accumulated much less ROS than the WT plants, while the Ri plants accumulated similar levels of ROS to those in the WT plants (Fig. $5 \mathrm{~A})$.

Furthermore, the potential functions of SISTE1 in oxidative stress were tested using methyl viologen (MV), an herbicide that induces superoxide radicals in chloroplasts. The growth of WT seedlings on $1 / 2$ MS medium containing MV was hypersensitive, and their root and shoot lengths were significantly shorter than those of the OE plants under $5 \mu \mathrm{M}$ MV treatment, while no obvious difference was observed in root and shoot lengths between the WT and OE plants grown under $10 \mu \mathrm{M}$ MV (Fig. 5B-E). Taken together, these results suggest that SISTE1 -OE plants exhibit improved adaptive ability to salt stress by affecting ROS levels.

\section{SISTE1 affects the transcription of diverse abiotic and biotic stress- and hormone-related genes under salt stress}

To elucidate the potential molecular mechanisms of salt tolerance mediated by SISTE1, changes in the global expression profiles of twoSlSTE1 -OE lines (OE-1 and -6) under $\mathrm{NaCl}$ stress were examined using RNA-seq. A summary of the sequencing assembly is shown in Table S3. At least $94.31 \%$ of the unigenes were mapped to the tomato genome for each library, and the RNA data displayed strong expression correlations $\left(\mathrm{R}^{2}[?]\right.$ 0.973, Fig. S4). A total of 1330 DEGs (differentially expressed genes) including 599 upregulated and 731 downregulated genes in the OE plants compared to those in the WT plants were detected, respectively (Fig. $6 \mathrm{~A}-\mathrm{D}$, Table S4). When the enrichment of the DEGs was analysed for GO annotation, multiple groups of genes related to stress-responsive GO terms, such as the response to stress, oxidative stress, osmotic stress, abiotic stimulus, stress-related transcription factor and multiple secondary metabolic processes were found (Fig. 6E, Fig. S5, Table S5). Moreover, DEG-associated KEGG pathways were also identified. It is noteworthy that the pathways related to hormone signalling and phenylpropanoid biosynthesis were the only two specially enriched terms among the DEGs in the OE-1/6 plants compared to those in the WT plants under salt stress (Fig. S6, Table S6).

Among the DEGs, 200 genes encoding various TFs were upregulated, and 193 of them were downregulated in the OE plants compared to those in the WT plants under salt stress (Table S4). Representative upreg- 
ulated TF genes are shown in Table 1 and included salt tolerance/stress-related ERF, Zinc finger protein, WRKY and MYB, etc. Likewise, the downregulated TFs included ERF, MYB, Homeobox, Zinc finger and NAC protein, etc. The results indicated that the overexpression of SISTE1 affects diverse types of downstream regulators. In addition, the induced genes putatively involved the stress response, and encompassed stress-related proteins, peroxidases, transports, secondary metabolisms and kinases, etc. (Table 2). For instance, multiple upregulated genes encoded PPR proteins, dehydration-responsive proteins, peroxidase, $\mathrm{ABC}$ transporter family proteins and the calcium-transporting ATPase, etc.

Moreover, to identify hormone compounds differentially accumulated in the SlSTE1 -OE and WT plants, DEGs associated with hormone synthesis and signalling were also selected. The differentially expressed genes were primarily involved in the ethylene, auxin and ABA signalling pathways (Table S7).

\section{Validation of differentially expressed genes in SISTE1 -OE and -Ri plants}

To validate the RNA-seq data, a total of 25 genes involved in transcriptional regulation, metabolic pathways or signal transduction were selected for qRT-PCR analysis under control and salt stress conditions $(24 \mathrm{~h}$, $300 \mathrm{mM} \mathrm{NaCl}$ ). The TF group encompassed genes encoding one Dof TF (SlDof14) (Cai et al. , 2013), five ERF TFs (SlERF15, 16, 25, 80, and 85) (Sharma et al. , 2010), one MYB TF (SlMYB15) (Huang et al. , 2012), two WRKY TFs (SlWRKY38 and SIWRKY54) (Huang et al. , 2012) and three Zinc finger proteins. The transcript levels of SlERF16,SlERF80, SlERF85 and SlWRKY54 were significantly upregulated and downregulated in plants from at least one $\mathrm{OE}$ and Ri line, respectively, compared to those in WT plants under control conditions. In addition, the expression of SlDof14 ,SlMYB15, SlWRKY38 and two Zinc finger protein genes decreased in plants from both the $\mathrm{OE}$ and the Ri lines under control conditions. When subjected to salt stress, the transcripts of most genes detected were 2-11-fold higher in the OE plants than in those in the WT plants (Fig. 6F, Fig. S7A).

Additional genes associated with various stress-related proteins and physiological/metabolic processes, such as F-box protein, heat shock protein, calmodulin-binding protein, PPR protein, receptor-like kinase (RLK), protein kinase and PAL, etc. were also detected. The transcript levels of multiple genes were lower in both the OE and the Ri plants than in the WT plants under control conditions, while most of the chose genes displayed elevated expression in OE plants, despite some variation in the expression of several genes in the transgenic plants after $\mathrm{NaCl}$ stress (Fig. 6G, Fig. S7B). Taken together, these results support the findings of the RNA-seq data and the hypothesis that SISTE1 is involved in modulating numerous and diverse stress-responsive genes in the tomato response to salt stress.

\section{SlSTE1-OE plants show altered sensitivity to ABA but not to ACC}

Since SISTE1 mRNA was upregulated by ABA and ACC, and the expression of ABA- and ethylene-related genes was altered in SlSTE1 transgenic plants, we hypothesized that SlSTE1 is involved in the tomato salt response via the ABA- and/or ACC-dependent pathways. To confirm this, seedling growth performance was evaluated in $1 / 2 \mathrm{MS}$ medium containing 0,3 , and $6 \mu \mathrm{M}$ ABA. No obvious differences were observed in the length of shoots and roots between the WT and Ri plants after $10 \mathrm{~d}$ following treatment with 3 and $6 \mu \mathrm{M}$ ABA (Fig. 7A-D). However, the growth of the OE plants was inhibited more severely than that of WT plants following ABA treatment. 10 days after sowing, the average lengths of both the shoots and roots of OE plants were shorter than those of the WT plants, especially the roots in the OE plants were remarkably shorter than those in the WT plants (Fig. 7E-H). These results suggest that the overexpression of SlSTE1 confers increased $\mathrm{ABA}$ sensitivity to tomato during post-germination growth.

Furthermore, the sensitivity of the SISTE1- OE plants to ACC was also detected. Seedlings of the WT and OE plants did not obviously differ, and no significant difference was detected in the lengths of the shoots and roots of the WT and OE plants $10 \mathrm{~d}$ after planting following treatment with 0 and $10 \mu \mathrm{M}$ ACC (Fig. S8). These results demonstrate thatSISTE1 might play an essential role in the response to salt stress mediated by ABA. 


\section{Altered expression of ABA signal transduction-related genes in SlSTE1 -OE plants}

To clarify the roles of SISTE1 in tomato salt tolerance via ABA-dependent pathways, the expression of ABA signal transduction-related genes was investigated. The transcription of 12 ABA receptor-encoding genes (SlPYLs ), 8 positive ABA signalling regulator genes (SlSnRK2s ), 7 negative ABA signalling regulator genes (SlPP2Cs ), and 2 ABA-responsive element binding factor genes (SlABFs ) was analysed under treatment with $100 \mu \mathrm{M}$ ABA. The results showed that the transcription of most SlPYLs was changed in the WT and OE plants with ABA treatment at 0 and $4 \mathrm{~h}$. The expression of SlPYL1 , 4-7, 11 and 12 was increased in the OE plants compared with that in the WT plants at $0 \mathrm{~h}$, and the significantly upregulated expression of SlPYL9 and 10 was detected $4 \mathrm{~h}$ after ABA treatment (Fig. 7I). The transcription of most SlSnRK2s did not differ remarkably between the WT and OE plants. The expression of most SlPP2Cs and SlABFs also did not differ remarkably between the WT and OE plants, except that SIPP2C3 was upregulated in the OE plants at $4 \mathrm{~h}$ after treatment (Fig. S9). These results indicate that SISTE1 is critical for modulating the expression of ABA-related genes.

\section{SISTE1 interacts with the ABA receptor SIPYLs and the positive ABA signalling regulator SISnRK2s}

The increased sensitivity to ABA and altered transcription of ABA signalling-related genes in the SlSTE1 -OE plants prompted us to further examine the potential interaction between SISTE1 and ABA receptor proteins (SlPYLs), positive ABA signalling regulators (SlSnRK2s), and negative ABA signalling regulators (SlPP2Cs).SlSTE1 was fused to the N-terminal domain of firefly luciferase (LUC) and 12 SlPYLs , 8 SlSnRK2s and 7 SlPP2Cs were fused to the C-terminal domain of LUC. Then we co-transformed SlSTE1nLUC/empty nLUC with the SIPYLs-, SIPP2Cs-, and SISnRK2s-cLUC into N. benthamiana leaves. No interactions were observed between the empty nLUC vector and Cluc vectors containing the 12 SIPYLs, 8 SlSnRK2s and 7 SlPP2Cs (Fig. S10). The results showed that SlSTE1 was able to interact with SIPYL5 and SIPYL8 in 12 SIPYL proteins detected, As for SlSnRK2s, coexpression of SlSTE1-nLUC with SlSnRK2.1/2.2/2.6/2.7/2.8-cLUC, but not SlSnRK2.3/2.4/2.5-cLUC produced measurable luciferase activity. No interactions were observed between SlSTE1 and all of the 7 SlPP2Cs tested (Fig. 8A). Then the interaction between SISTE1 and SIPYL5, SISnRK2.1 and SISnRK2.2 was further verified by BiFC assay. The EYFP fluorescence signal was observed when pSAT6-nEYFP-SlSTE1 and pSAT6-cEYFP-SlPYL5/SlSnRK2.1/-SlSnRK2.2 were co-transformed into onion epidermal cells, while empty pSAT6-nEYFP could not recover EYFP fluorescence when expressed with the three genes-fused pSAT6-cEYFP and empty pSAT6cEYFP (Fig. 8B). These results suggest that SISTE1 can modulate the ABA pathway by interacting with SlPYLs and SlSnRK2s in tomato.

\section{DISCUSSION}

Tomato plants are moderately sensitive to salt at all stages of development, especially during germination and subsequent seedling growth (Kaveh et al. , 2011). However, the specific mechanisms of salt stress responses and their relationships with the ABA signalling networks in tomato, compared with those in the model plants Arabidopsis and rice remain largely unknown. Herein, we report that the tomato SlSTE1 protein without any known conserved domains, plays a role in ABA and salt signalling.

\section{SISTE1 improves ion homeostasis in the tomato salt stress response}

Ion toxicity and osmotic adjustment are two main factors that plants must confront when suffering from salt stress (Munns et al. , 2008). Specific $\mathrm{Na}^{+}$toxicity and salinity-induced $\mathrm{K}^{+}$deficiency are two major constraints in salinized plants; thus, maintaining the balance of $\mathrm{Na}^{+}$and $\mathrm{K}^{+}$is critical for detoxifying excessive $\mathrm{Na}^{+}$ionic damage in salinity-affected plants (Wei et al. , 2017). In this study, $\mathrm{Na}^{+}$fluorescence was lower in the roots of $\mathrm{OE}$ lines than in the roots of WT plants after $\mathrm{NaCl}$ treatment. In addition, 
decreased $\mathrm{K}^{+}$efflux and increased $\mathrm{H}^{+}$efflux in the roots of OE plants were detected by NMT under $\mathrm{NaCl}$ stress. The data were consistent with the higher $\mathrm{K}^{+} / \mathrm{Na}^{+}$ratios observed in the OE plants compared with those in the WT plants, suggesting less $\mathrm{Na}^{+}$accumulation and $\mathrm{K}^{+}$leakage in OE plants than those in WT plants under salt stress. For plants, limited $\mathrm{Na}^{+}$uptake, increased $\mathrm{Na}^{+}$exclusion back to the soil via the PM SOS1 $\mathrm{Na}^{+} / \mathrm{H}^{+}$antiporter and the sequestration of excessive $\mathrm{Na}^{+}$into vacuoles by the tonoplast $\mathrm{Na}^{+} / \mathrm{H}^{+}$ exchanger (NHX) are considered to be central responses to salinity stress (Munns et al. , 2008, Yu et al. , 2015). In addition, LKT ( $\mathrm{K}^{+}$uptake channel) and $\mathrm{PM} \mathrm{H}^{+}$-ATPases (LHA) also play a role in $\mathrm{Na}^{+}$and $\mathrm{K}^{+}$transport in tomatoes under salinity conditions (Hartje et al. , 2000, Kalampanayil et al. , 2001). Our results revealed that the transcription of genes related to the regulation of ion homeostasis including SlLKT1 ,SlNHX1 -3 , SlLHA1-2 and SlSOS1-2 was enhanced in the OE plants. Thus, it is suggested that SlSTE1 might contribute to improving salt tolerance by increasing $\mathrm{Na}^{+}$exclusion and $\mathrm{K}^{+}$uptake in plant cells. Collectively, the data suggest that the salt tolerance of theSISTE1 -OE plants might be partly attributed to the improved ion homeostasis under salt stress.

\section{Enhanced ROS scavenging capacity confers improved salt tolerance to SlSTE1 -OE plants}

Ionic or ion-toxicity effects on plant cells are typical primary signals caused by salt stress. Salinity stress often induces complex secondary effects including oxidative stress, damage to cellular components such as membrane lipids, proteins and nucleic acids (Zhu, 2016). Massive documents have shown that ROSscavenging systems against $\mathrm{H}_{2} \mathrm{O}_{2}$ accumulation and toxicity are involved in plant salt tolerance $(\mathrm{Xu}$ et al. , 2018). Consistent with previous results, OE plants displayed enhanced tolerance to salt and oxidative stress, with a corresponding elevation in the activities of antioxidant enzymes (CAT and SOD) compared to those in the WT plants, which might partly explain their reduced ROS accumulation. Moreover, ABA, chlorophyll and MDA levels are usually regarded as indices of the stress damage to plants (Roy et al., 2006, Zhu et al. , 2018). The present survey showed that levels of ABA and chlorophyll were obviously increased, whereas MDA levels were decreased in OE plants compared to those in the WT plants under salt stress. In this context, enhanced MDA, ABA and chlorophyll contents have also been observed inSlAREB1 and SlDREB2 transgenic tomato plants with improved salt tolerance (Hichri et al. , 2016, Orellana et al. , 2010). The data show that the significantly enhanced activities of ROS-scavenging enzymes contributed to less ROS accumulation and thus reduced oxidative damage in SISTE1 -OE plants compared to that in WT plants, which is related to the increased salt tolerance.

An imbalance between ROS production and detoxification generates oxidative stress, and accumulated ROS are harmful to plants. However, specific ROS also function as signalling molecules and activate signal transduction processes in response to multiple stresses (Tripathy et al. ,2012). Previous reports demonstrated that ROS are important integral parts of ABA signalling pathways in plant guard cells, and the functions of $\mathrm{ABA}$ in the environmental stress response via redox metabolism have been elucidated (He et al. , 2012, Xu et al. , 2018). In addition to the reduced ROS accumulation, increased ABA sensitivity was also observed in the SISTE1 -OE plants, which indicated that changes in ROS might correlate with ABA sensitivity. Previous findings showed that altered ROS accumulation can affect ABA synthesis, signalling and sensitivity (Verslues et al. , 2007), and ABA can also modulate the transcription of ROS-producing and -scavenging genes (Jiang et al. , 2002). For instance, a recent document revealed that the rice TF OsMADS25 is a negative regulator of ROS production but positively regulates ABA sensitivity. The overexpression of $\mathrm{Os}_{\text {- }}$ MADS25 decreased $\mathrm{H}_{2} \mathrm{O}_{2}$-induced inhibition by regulating the expression of ROS-producers and -scavengers and the activities of ROS-scavenging enzymes (Xuet al. , 2018). Along with elevated ROS levels, ABA signalling and ABA-dependent metabolic changes have been proposed to be vital components of cross-tolerance to different stresses (Pastori et al. , 2002). Therefore, these data suggest that the mechanisms of ABA signalling and ROS production may be different, that they may interact and affect each other, and that SlSTE1 may participate in the interaction between ABA signalling and ROS production in tomato. 


\section{SISTE1 confers salt tolerance via ABA-mediated pathways}

The phytohormone ABA is regarded as the major signal that activates the expression of stress-related genes (Leeet al. , 2012). SlSTE1 was upregulated by $\mathrm{NaCl}$ stress and ABA treatment, which was consistent with previous results (Aboul-Soud et al. , 2009). Subsequently, enhanced salt tolerance was detected during the post-germination and adult stages in SISTE1 -OE plants, while reduced salt tolerance was observed in the corresponding periods ofSISTE1 -Ri plants compared to that in the WT plants. Meanwhile, improved tolerance to $\mathrm{KCl}$ and $\mathrm{LiCl}$ was also observed in the OE seedlings, suggesting that the SISTE1 -OE plants confer different types of salt tolerance and are not specific to the sodium response. Furthermore, the enhanced salt tolerance of $\mathrm{OE}$ plants was characterized by the upregulated transcription of numerous and diverse types of downstream stress regulators compared to that in the WT plants. A total of 1330 DEGs were detected in OE lines vs WT under salt stress. For instance, the upregulated genes in salt-treated OE plants involved the stress response and encompassed many types of TFs (such as Dof, ERF, WRKY and MYB), stress-related proteins (such as PPR and F-box), peroxidases, transports (such as ABC transporter and calcium-transporting ATPase), secondary metabolisms (such as PAL and pectinesterase) and kinases (such as RLK and MAPKKK), etc. These factors have been shown to be widely involved in plant responses to various stresses in tomato and other plant species (Cai et al. , 2013, Chen et al. , 2018, Huang et al. , 2012, Jia et al. , 2017, Jie et al. , 2014, Lv et al. , 2014, Phimchan et al. , 2014, Sharma et al. , 2010, Wei et al. , 2015). The transcription of these stress-responsive genes leads to alterations of biochemical and physiological pathways and the accumulation of metabolites that are critical for plant adaptation to environmental stresses, consequently making the SISTE1 -OE plants more tolerant to salinity. Collectively, these data show that SISTE1 has diverse roles because it can affect numerous stress signalling pathways, and salt tolerance conferred by SISTE1 might be due to the superimposition of the effects of different signalling pathways.

An ABA-hypersensitive phenotype was observed in SISTE1 -OE plants during the post-germination stages. The transcripts of multiple ABA receptor-encoding genes SlPYLs were more abundant in the OE seedlings than those in the WT seedlings. Moreover, the SISTE1 -OE plants tended to accumulate more ABA than the WT plants under salt stress, which partly explained the enhanced salt tolerance of the OE lines because, as a pivotal stress hormone, high levels of ABA may accelerate and/or strengthen the plant stress response (Zhu, 2016, Zhu et al. , 2018). Moreover, the transcription levels of many abiotic stress-responsive genes triggered by ABA (Buchanan et al. , 2005, Matsui et al. , 2008) and ABA synthesis- and signal transductionrelated genes were also altered in the SISTE1 -OE plants under salt stress. In addition, our results suggest that SISTE1 can affect the ABA pathway by interacting with the ABA receptors SIPYLs and positive ABA signalling regulator SISnRK2s in tomato. Therefore, our findings provide firm evidence for a positive role of SISTE1 in salt tolerance via a stress-responsive ABA-mediated signalling pathway in tomato.

Altogether, our results suggest that the functional involvement of SISTE1 in defence mechanisms against salt stress is associated with ABA-mediated signalling, enhanced ROS scavenging capacity and $\mathrm{K}^{+} / \mathrm{Na}^{+}$ homeostasis. The overexpression of SlSTE1 also affects the transcription of numerous stress-responsive genes, and integrates other beneficial properties, such as tolerance to different types of salt stress and oxidative stress. Therefore, our findings suggest that SISTE1 promotes ABA-dependent salt stress-responsive pathways via improving ion homeostasis and ROS scavenging in tomato.

\section{ACKNOWLEDGMENTS}

This work was supported by the National Natural Science Foundation of China (31700226), the Priority Academic Program Development of Jiangsu Higher Education Institutions (PAPD) and the postgraduate research \& practice innovation program of Jiangsu province (KYCX17-1619).

\section{CONFLICT OF INTEREST}

Authors declare no conflicts of interest.

\section{REFERENCES}


Aboul-Soud M.A. \& El-Shemy H.A. (2009) Identification and subcellular localisation of Sl;INT7: A novel tomato (Solanum lycopersicum Mill.) fruit ripening-related and stress-inducible gene. Plant science, 176 , 241-247.

Acosta-Motos J.R., Diaz-Vivancos P., Álvarez S., Fernández-García N., Sánchez-Blanco M.J. \& Hernández J.A. (2015) NaCl-induced physiological and biochemical adaptative mechanisms in the ornamental Myrtus communis L. plants. Journal of plant physiology, 183, 41-51.

Ali A., Muzaffar A., Awan M.F., Din S., Nasir I.A. \& Husnain T. (2014) Genetically Modified Foods: Engineered tomato with extra advantages. Adv. life sci ,1 , 139-152.

Anders S. \& Huber W. (2010) Differential expression analysis for sequence count data. Genome biology, 11 , R106.

Apse M.P. \& Blumwald E. (2002) Engineering salt tolerance in plants. Current Opinion in Biotechnology, $13,146-150$.

Bartels D. \& Sunkar R. (2005) Drought and Salt Tolerance in Plants. Critical Reviews in Plant Sciences ,24 , 23-58.

Buchanan C.D., Lim S., Salzman R.A., Kagiampakis I., Morishige D.T., Weers B.D., Klein R.R., Pratt L.H., Cordonnier-Pratt M.-M. \& Klein P.E. (2005) Sorghum bicolor's transcriptome response to dehydration, high salinity and ABA.Plant molecular biology , 58, 699-720.

Cai X., Zhang Y., Zhang C., Zhang T., Hu T., Ye J. \& Zhang J. (2013) Genome-wide Analysis of Plantspecific Dof Transcription Factor Family in Tomato. Journal of integrative plant biology , 55 , 552-566.

Chen H., Zou Y., Shang Y., Lin H., Wang Y., Cai R., Tang X. \& Zhou J.-M. (2008) Firefly luciferase complementation imaging assay for protein-protein interactions in plants. Plant physiology, 146 , 368-376.

Chen N., Song B., Tang S., He J., Zhou Y., Feng J., Shi S. \& Xu X. (2018) Overexpression of the ABC transporter gene TsABCG11 increases cuticle lipids and abiotic stress tolerance in Arabidopsis. Plant Biotechnology Reports , 12 , 303-313.

Citovsky V., Lee L.-Y., Vyas S., Glick E., Chen M.-H., Vainstein A., Gafni Y., Gelvin S.B. \& Tzfira T. (2006) Subcellular localization of interacting proteins by bimolecular fluorescence complementation in planta. Journal of Molecular Biology , 362, 1120-1131.

Fernando V.D. \& Schroeder D.F. (2016) Role of ABA in Arabidopsis salt, drought, and desiccation tolerance. In: Abiotic and Biotic Stress in Plants-Recent Advances and Future Perspectives . InTech.

Foolad M.R. (2004) Recent Advances in Genetics of Salt Tolerance in Tomato. Plant Cell Tissue 85 Organ Culture, $\mathbf{7 6}$, 101-119.

Fujii H., Chinnusamy V., Rodrigues A., Rubio S., Antoni R., Park S.Y., Cutler S.R., Sheen J., Rodriguez P.L. \& Zhu J.K. (2009) In vitro reconstitution of an abscisic acid signalling pathway. Nature, 462, 660-664.

Hartje S., Zimmermann S., Klonus D. \& Mueller-Roeber B. (2000) Functional characterisation of LKT1, a $\mathrm{K}^{+}$uptake channel from tomato root hairs, and comparison with the closely related potato inwardly rectifying $\mathrm{K}^{+}$channel SKT1 after expression in Xenopus oocytes . Planta, 210 , 723-731.

He J., Duan Y., Hua D., Fan G., Wang L., Liu Y., Chen Z., Han L., Qu L.-J. \& Gong Z. (2012) DEXH box RNA helicase-mediated mitochondrial reactive oxygen species production inArabidopsis mediates crosstalk between abscisic acid and auxin signaling. The Plant Cell , 24, 1815-1833.

Hichri I., Muhovski Y., Clippe A., Žižková E., Dobrev P.I., Motyka V. \& Lutts S. (2016) SIDREB2, a tomato dehydration-responsive element-binding 2 transcription factor, mediates salt stress tolerance in tomato and Arabidopsis . Plant, cell \&3 environment, 39 , 62-79. 
Hu W., Huang C., Deng X., Zhou S., Chen L., Li Y., Wang C., Ma Z., Yuan Q. \& Wang Y. (2013) TaASR1, a transcription factor gene in wheat, confers drought stress tolerance in transgenic tobacco. Plant, cell $\mathcal{E}$ environment, $\mathbf{3 6}, 1449-1464$.

Huang K.-C., Lin W.-C. \& Cheng W.-H. (2018) Salt hypersensitive mutant 9, a nucleolar APUM23 protein, is essential for salt sensitivity in association with the ABA signaling pathway in Arabidopsis. BMC plant biology $, \mathbf{1 8}, 40$.

Huang S., Gao Y., Liu J., Peng X., Niu X., Fei Z., Cao S. \& Liu Y. (2012) Genome-wide analysis of WRKY transcription factors in Solanum lycopersicum. Molecular Genetics $\& 3$ Genomics Mgg, 287 , 495-513.

Jia Q., Xiao Z.-X., Wong F.-L., Sun S., Liang K.-J. \& Lam H.-M. (2017) Genome-wide analyses of the soybean F-box gene family in response to salt stress. International journal of molecular sciences , 18 , 818.

Jiang M. \& Zhang J. (2002) Water stress-induced abscisic acid accumulation triggers the increased generation of reactive oxygen species and up-regulates the activities of antioxidant enzymes in maize leaves. Journal of experimental botany, 53, 2401-2410.

Jie W., Pan C., Yan W., Lei Y., Jian W., Chen L., Tao Z. \& Gang L. (2014) Genome-Wide Identification of MAPKK and MAPKKK Gene Families in Tomato and Transcriptional Profiling Analysis during Development and Stress Response. Plos One ,9 , e103032.

Kalampanayil B. \& Wimmers L. (2001) Identification and characterization of a salt-stress-induced plasma membrane $\mathrm{H}^{+}$-ATPase in tomato. Plant, Cell $\&$ Environment, 24 , 999-1000.

Kant P., Kant S., Gordon M., Shaked R. \& Barak S. (2007) STRESS RESPONSE SUPPRESSOR1 and STRESS RESPONSE SUPPRESSOR2, two DEAD-box RNA helicases that attenuateArabidopsis responses to multiple abiotic stresses. Plant Physiology , 145, 814-830.

Kaveh H., Nemati H., Farsi M. \& Jartoodeh S. (2011) How salinity affect germination and emergence of tomato lines. Journal of Biological and Environmental Sciences ,5 , 159-163.

Kumar J., Singh S., Singh M., Srivastava P.K., Mishra R.K., Singh V.P. \& Prasad S.M. (2017) Transcriptional regulation of salinity stress in plants: A short review.Plant Gene, 11, 160-169.

Lee S.C. \& Luan S. (2012) ABA signal transduction at the crossroad of biotic and abiotic stress responses.Plant Cell \&3 Environment, 35, 53.

Løvdal T. \& Lillo C. (2009) Reference gene selection for quantitative real-time PCR normalization in tomato subjected to nitrogen, cold, and light stress. Analytical Biochemistry , 387 , 238-242.

Lv H.-X., Huang C., Guo G.-Q. \& Yang Z.-N. (2014) Roles of the nuclear-encoded chloroplast SMR domaincontaining PPR protein SVR7 in photosynthesis and oxidative stress tolerance in Arabidopsis. Journal of Plant Biology ,57, 291-301.

Ma Y., Szostkiewicz I., Korte A., Moes D., Yang Y., Christmann A. \& Grill E. (2009) Regulators of PP2C phosphatase activity function as abscisic acid sensors. Science ,324, 1064-1068.

Matsui A., Ishida J., Morosawa T., Mochizuki Y., Kaminuma E., Endo T.A., Okamoto M., Nambara E., Nakajima M. \& Kawashima M. (2008) Arabidopsis transcriptome analysis under drought, cold, high-salinity and ABA treatment conditions using a tiling array. Plant and Cell Physiology , 49 , 1135-1149.

Meng X., Li G., Gu L., Sun Y., Li Z., Liu J., Wu X., Dong T. \& Zhu M. (2019) Comparative Metabolomic and Transcriptome Analysis Reveal Distinct Flavonoid Biosynthesis Regulation Between Petals of White and Purple Phalaenopsis amabilis. Journal of Plant Growth Regulation, 1-18.

Munns R. \& Tester M. (2008) Mechanisms of salinity tolerance. Annual Review of Plant Biology ,59 , 651-681. 
Orellana S., Yanez M., Espinoza A., Verdugo I., Gonzalez E., RUIZ-LARA S. \& Casaretto J.A. (2010) The transcription factor SlAREB1 confers drought, salt stress tolerance and regulates biotic and abiotic stress-related genes in tomato.Plant, Cell \& Environment, 33, 2191-2208.

Park S.-Y., Fung P., Nishimura N., Jensen D.R., Fujii H., Zhao Y., Lumba S., Santiago J., Rodrigues A. \& Tsz-fung F.C. (2009) Abscisic acid inhibits type 2C protein phosphatases via the PYR/PYL family of START proteins. science, 324, 1068-1071.

Pastori G.M. \& Foyer C.H. (2002) Common components, networks, and pathways of cross-tolerance to stress. The central role of "redox" and abscisic acid-mediated controls.Plant physiology , 129, 460-468.

Phimchan P., Chanthai S., Bosland P.W. \& Techawongstien S. (2014) Enzymatic changes in phenylalanine ammonia-lyase, cinnamic-4-hydroxylase, capsaicin synthase, and peroxidase activities in capsicum under drought stress. Journal of Agricultural \& Food Chemistry, 62, 7057-7062.

Roy R., Purty R.S., Agrawal V. \& Gupta S.C. (2006) Transformation of tomato cultivar 'Pusa Ruby' withbspA gene from Populus tremula for drought tolerance.Plant Cell Tissue $\mathcal{E}$ Organ Culture , 84 , 56-68.

Seki M., Kamei A., Yamaguchi-Shinozaki K. \& Shinozaki K. (2003) Molecular responses to drought, salinity and frost: common and different paths for plant protection. Current Opinion in Biotechnology, 14, 194-199.

Sharma M.K., Kumar R., Solanke A.U., Sharma R., Tyagi A.K. \& Sharma A.K. (2010) Identification, phylogeny, and transcript profiling of ERF family genes during development and abiotic stress treatments in tomato. Molecular Genetics 83 Genomics , 284, 455-475.

Sun J., Chen S., Dai S., Wang R., Li N., Shen X., Zhou X., Lu C., Zheng X. \& Hu Z. (2009) NaCl-induced alternations of cellular and tissue ion fluxes in roots of salt-resistant and salt-sensitive poplar species. Plant physiology , 149 , 1141-1153.

Tripathy B.C. \& Oelmüller R. (2012) Reactive oxygen species generation and signaling in plants. Plant signaling \&3 behavior, $7,1621-1633$.

Umezawa T., Sugiyama N., Mizoguchi M., Hayashi S., Myouga F., Yamaguchi-Shinozaki K., Ishihama Y., Hirayama T. \& Shinozaki K. (2009) Type 2C protein phosphatases directly regulate abscisic acid-activated protein kinases in Arabidopsis.Proceedings of the National Academy of sciences, 106 , 17588-17593.

Verslues P.E., Kim Y.-S. \& Zhu J.-K. (2007) Altered ABA, proline and hydrogen peroxide in an Arabidopsis glutamate: glyoxylate aminotransferase mutant. Plant molecular biology , 64, 205-217.

Wei D., Zhang W., Wang C., Meng Q., Li G., Chen T.H. \& Yang X. (2017) Genetic engineering of the biosynthesis of glycinebetaine leads to alleviate salt-induced potassium efflux and enhances salt tolerance in tomato plants. Plant science, 257, 74-83.

Wei Z., Wang J., Yang S. \& Song Y. (2015) Identification and expression analysis of the LRR-RLK gene family in tomato (Solanum lycopersicum ) Heinz 1706. Genome ,58, 121-134.

Xu N., Chu Y., Chen H., Li X., Wu Q., Jin L., Wang G. \& Huang J. (2018) Rice transcription factor OsMADS25 modulates root growth and confers salinity tolerance via the ABA-mediated regulatory pathway and ROS scavenging. PLoS genetics, $\mathbf{1 4}$, e1007662.

Yi C., Yao K., Cai S., Li H., Zhou J., Xia X., Shi K., Yu J., Foyer C.H. \& Zhou Y. (2015) High atmospheric carbon dioxide-dependent alleviation of salt stress is linked to RESPIRATORY BURST OXIDASE 1 (RBOH1)-dependent $\mathrm{H} 2 \mathrm{O} 2$ production in tomato (Solanum lycopersicum ). Journal of experimental botany ,66, 7391-7404.

Yu Y., Xu T., Li X., Tang J., Ma D., Li Z. \& Sun J. (2015) NaCl-induced changes of ion homeostasis and nitrogen metabolism in two sweet potato (Ipomoea batatas L.) cultivars exhibit different salt tolerance at adventitious root stage.Environmental and Experimental Botany, 129, 23-36. 
Zhang X., Ja T.D.S., Duan J., Deng R., Xu X. \& Ma G. (2012) Endogenous hormone levels and anatomical characters of haustoria in Santalum album L. seedlings before and after attachment to the host. Journal of Plant Physiology ,169, 859-866.

Zhu J. (2002) Salt and drought stress signal transduction in plants. Annual Review of Plant Biology ,53 , 247-273.

Zhu J.K. (2016) Abiotic stress signaling and responses in plants. Cell , 167, 313-324.

Zhu M., Chen G., Dong T., Wang L., Zhang J., Zhao Z. \& Hu Z. (2015) SIDEAD31 , a putative DEAD-box RNA helicase gene, regulates salt and drought tolerance and stress-related genes in tomato. PloS one, 10, e0133849.

Zhu M., Meng X., Cai J., Li G., Dong T. \& Li Z. (2018) Basic leucine zipper transcription factor SlbZIP1 mediates salt and drought stress tolerance in tomato. BMC plant biology , 18, 83 .

Tables

Table 1. Selected TFs encoding genes differently upregulated or downregulated $\left(\mid \log _{2}\right.$ fold $\mid>1.0$ and padj $<0.05)$ in the SISTE1 -OE transgenic plants OE-1 and -6 compared to WT plants. Nd, not detected; padj, adjusted $\mathrm{P}$ value.

\begin{tabular}{|c|c|c|c|c|c|}
\hline TF family & Accession & $\begin{array}{l}\log _{2} \text { fold } \\
(\mathrm{OE}-1 / \mathrm{WT})\end{array}$ & padj & $\begin{array}{l}\log _{2} \text { fold } \\
(\mathrm{OE}-6 / \mathrm{WT})\end{array}$ & padj \\
\hline Upregulated & Upregulated & Upregulated & Upregulated & Upregulated & Upregulated \\
\hline TF genes & TF genes & TF genes & TF genes & TF genes & TF genes \\
\hline \multirow[t]{14}{*}{$\mathrm{ERF}$} & Solyc06g054630.2 & 3.0719 & 0.0050 & 3.8547 & 0.0000 \\
\hline & Solyc01g108240.3 & $\mathrm{Nd}$ & $\mathrm{Nd}$ & 3.0469 & 0.0021 \\
\hline & Solyc08g080290.3 & 2.4914 & 0.0213 & 2.7186 & 0.0229 \\
\hline & Solyc02g090800.1 & $\mathrm{Nd}$ & $\mathrm{Nd}$ & 2.5998 & 0.0005 \\
\hline & Solyc06g035700.1 & 2.4891 & 0.0464 & 2.5840 & 0.0357 \\
\hline & Solyc08g007830.1 & $\mathrm{Nd}$ & $\mathrm{Nd}$ & 2.1999 & 0.0000 \\
\hline & Solyc02g090770.1 & 1.9303 & 0.0000 & 2.4067 & 0.0000 \\
\hline & Solyc12g009240.1 & 1.9453 & 0.0238 & 2.2271 & 0.0070 \\
\hline & Solyc11g061750.2 & 1.9863 & 0.0176 & $\mathrm{Nd}$ & $\mathrm{Nd}$ \\
\hline & Solyc03g026270.2 & 1.6700 & 0.0202 & 1.8526 & 0.0070 \\
\hline & Solyc04g051360.3 & $\mathrm{Nd}$ & $\mathrm{Nd}$ & 1.5818 & 0.0131 \\
\hline & Solyc11g042560.1 & 1.2487 & 0.0049 & $\mathrm{Nd}$ & $\mathrm{Nd}$ \\
\hline & Solyc10g050970.1 & 1.0427 & 0.0002 & 1.3909 & 0.0000 \\
\hline & Solyc08g078190.1 & 1.0114 & 0.0000 & 1.2742 & 0.0000 \\
\hline \multirow{2}{*}{$\begin{array}{l}\text { Zinc finger } \\
\text { protein }\end{array}$} & Solyc02g088670.1 & $\mathrm{Nd}$ & $\mathrm{Nd}$ & 3.8353 & 0.0433 \\
\hline & Solyc04g077980.1 & 0.9391 & 0.0000 & 1.2479 & 0.0000 \\
\hline \multirow[t]{2}{*}{ WRKY } & Solyc02g094270.2 & 3.7778 & 0.0006 & 3.0120 & 0.0255 \\
\hline & Solyc08g082110.3 & 1.4048 & 0.0018 & 1.1144 & 0.0416 \\
\hline \multirow[t]{2}{*}{ MYB } & Solyc02g090400.3 & 1.7265 & 0.0000 & 1.9134 & 0.0000 \\
\hline & Solyc09g090130.3 & 1.1091 & 0.0000 & 0.9959 & 0.0000 \\
\hline Homeobox & Solyc08g062330.3 & 1.1868 & 0.0043 & 1.2146 & 0.0094 \\
\hline Dof & Solyc03g121400.1 & 0.9181 & 0.0031 & 1.0074 & 0.0011 \\
\hline Downregulated & Downregulated & Downregulated & Downregulated & Downregulated & Downregulated \\
\hline TF genes & TF genes & TF genes & TF genes & TF genes & TF genes \\
\hline \multirow[t]{3}{*}{ ERF } & Solyc02g077810.1 & -1.7448 & 0.0016 & -1.4585 & 0.0105 \\
\hline & Solyc03g005520.1 & -1.6558 & 0.0250 & -1.6008 & 0.0392 \\
\hline & Solyc06g065820.3 & -0.6853 & 0.0305 & -1.4965 & 0.0000 \\
\hline
\end{tabular}




\begin{tabular}{llllll}
\hline TF family & Accession & $\begin{array}{l}\text { Log }_{\mathbf{2}} \text { fold } \\
(\mathbf{O E - 1 / W T})\end{array}$ & $\mathbf{p a d j}$ & $\begin{array}{l}\mathbf{L o g}_{2} \text { fold } \\
(\mathbf{O E - 6 / W T})\end{array}$ & $\mathbf{p a d j}$ \\
\hline \multirow{4}{*}{ MYB } & Solyc04g007000.1 & -1.3517 & 0.0001 & $\mathrm{Nd}$ & $\mathrm{Nd}$ \\
& Solyc01g090340.2 & $\mathrm{Nd}$ & $\mathrm{Nd}$ & -1.2900 & 0.0149 \\
& Solyc02g079280.3 & -1.6365 & 0.0020 & -1.1796 & 0.0490 \\
& Solyc10g005460.3 & -1.6167 & 0.0062 & -1.6144 & 0.0016 \\
Homeobox & Solyc05g053330.3 & -1.2568 & 0.0006 & $\mathrm{Nd}$ & $\mathrm{Nd}$ \\
& Solyc08g076400.3 & $\mathrm{Nd}$ & $\mathrm{Nd}$ & -1.0962 & 0.0131 \\
Zinc finger & Solyc02g077590.1 & -3.4130 & 0.0001 & -4.2243 & 0.0000 \\
protein & Solyc03g082550.3 & -1.7060 & 0.0000 & -1.4388 & 0.0000 \\
& Solyc02g085630.3 & -1.0044 & 0.0015 & $\mathrm{Nd}$ & $\mathrm{Nd}$ \\
\multirow{2}{*}{ NAC } & Solyc05g009170.2 & -2.7991 & 0.0000 & -2.0992 & 0.0000 \\
& & & & & \\
bHLH & Solyc03g119540.3 & $\mathrm{Nd}$ & $\mathrm{Nd}$ & -1.8281 & 0.0001 \\
& Solyc06g071580.3 & $\mathrm{Nd}$ & $\mathrm{Nd}$ & -1.0343 & 0.0041 \\
MADS & Solyc07g063410.3 & -1.6030 & 0.0000 & -0.9987 & 0.0000 \\
GRAS & Solyc12g013620.2 & -1.5995 & 0.0000 & -0.8613 & 0.0006 \\
E2F & Solyc01g098720.3 & -2.5059 & 0.0000 & -3.4533 & 0.0000 \\
\hline
\end{tabular}

Table 2. Selected gene products putatively involved stress response differently upregulated $\left(\log _{2}\right.$ fold $>1.0$ and padj $\left.<0.05\right)$ in the SlSTE1 -OE transgenic plants OE-1 and -6 compared to WT plants. Nd, not detected; padj, adjusted P value.

\begin{tabular}{|c|c|c|c|c|c|c|}
\hline Category & Accession & $\begin{array}{l}\text { Functional } \\
\text { annotation }\end{array}$ & $\begin{array}{l}\log _{2} \text { fold } \\
(\mathrm{OE}-1 / \mathrm{WT})\end{array}$ & padj & $\begin{array}{l}\log _{2} \text { fold } \\
(\mathrm{OE}-6 / \mathrm{WT})\end{array}$ & padj \\
\hline \multirow[t]{5}{*}{$\begin{array}{l}\text { Stress- } \\
\text { related } \\
\text { protein }\end{array}$} & \multicolumn{3}{|c|}{$\begin{aligned} & \text { Solyc08g078080.3 } \text { Pentatricopeptide1.9628 } \\
& \text { repeat- } \\
& \text { containing } \\
& \text { protein }\end{aligned}$} & 0.0194 & 2.2524 & 0.0050 \\
\hline & Solyc03g096460.3 & $\begin{array}{l}\text { Wound/stress } \\
\text { protein } \\
\text { precursor }\end{array}$ & 1.7749 & 0.0002 & $\mathrm{Nd}$ & $\mathrm{Nd}$ \\
\hline & Solyc01g102960.3 & $\begin{array}{l}22.7 \mathrm{kDa} \\
\text { class IV } \\
\text { heat shock } \\
\text { protein-like }\end{array}$ & 1.0088 & 0.0068 & 1.7678 & 0.0000 \\
\hline & Solyc07g040960.1 & $\begin{array}{l}\text { Salt } \\
\text { responsive } \\
\text { protein } 2\end{array}$ & 1.4189 & 0.0000 & 1.7345 & 0.0000 \\
\hline & Solyc03g020060.3 & $\begin{array}{l}\text { Proteinase } \\
\text { inhibitor II }\end{array}$ & 1.5054 & 0.0000 & 1.6202 & 0.0454 \\
\hline
\end{tabular}




\begin{tabular}{|c|c|c|c|c|c|c|}
\hline Category & Accession & $\begin{array}{l}\text { Functional } \\
\text { annotation }\end{array}$ & $\begin{array}{l}\log _{2} \text { fold } \\
(\mathrm{OE}-1 / \mathrm{WT})\end{array}$ & padj & $\begin{array}{l}\log _{2} \text { fold } \\
(\mathrm{OE}-6 / \mathrm{WT})\end{array}$ & padj \\
\hline & Solyc05g015300.3 & $\begin{array}{l}\text { Dehydration- } \\
\text { responsive } \\
\text { protein } \\
\text { RD22 }\end{array}$ & 1.2638 & 0.0185 & $\mathrm{Nd}$ & $\mathrm{Nd}$ \\
\hline \multirow[t]{3}{*}{ Peroxidase } & Solyc08g013930.3 & $\begin{array}{l}3 \text { Peroxidase } \\
61\end{array}$ & 3.3260 & 0.0000 & $\mathrm{Nd}$ & $\mathrm{Nd}$ \\
\hline & Solyc12g005370.2 & $\begin{array}{l}2 \text { Peroxidase } \\
27\end{array}$ & 2.5643 & 0.0232 & $\mathrm{Nd}$ & $\mathrm{Nd}$ \\
\hline & Solyc07g017880.3 & $\begin{array}{l}3 \text { Peroxidase } \\
16\end{array}$ & 1.7975 & 0.0013 & $\mathrm{Nd}$ & $\mathrm{Nd}$ \\
\hline \multirow[t]{7}{*}{ Transport } & Solyc01g106200.2 & $\begin{array}{l}\text { Oligopeptide } \\
\text { transporter } \\
4\end{array}$ & 1.5061 & 0.0004 & $\mathrm{Nd}$ & $\mathrm{Nd}$ \\
\hline & Solyc05g013890.2 & $\begin{array}{l}2 \mathrm{ABC} \\
\text { transporter } \\
\text { B family } \\
\text { member } \\
\text { 15-like }\end{array}$ & $\mathrm{Nd}$ & $\mathrm{Nd}$ & 1.5513 & 0.0138 \\
\hline & Solyc02g062890.2 & $\begin{array}{l}2 \text { Polyol } \\
\text { transporter } \\
6\end{array}$ & $\mathrm{Nd}$ & $\mathrm{Nd}$ & 1.5466 & 0.0377 \\
\hline & Solyc06g072620.3 & $\begin{array}{l}3 \text { Bidirectional } \\
\text { sugar } \\
\text { transporter } \\
\text { SWEET11- } \\
\text { like }\end{array}$ & $\mathrm{Nd}$ & $\mathrm{Nd}$ & 1.3623 & 0.0194 \\
\hline & Solyc06g060110.3 & $\begin{array}{l}\text { Amino acid } \\
\text { transporter } \\
2\end{array}$ & 1.4168 & 0.0000 & 1.3029 & 0.0000 \\
\hline & Solyc09g082870.2 & $\begin{array}{l}\text { Calcium- } \\
\text { transporting } \\
\text { ATPase } 1\end{array}$ & 1.6555 & 0.0000 & 1.3367 & 0.0063 \\
\hline & Solyc03g118810.1 & $\begin{array}{l}\text { Calcium- } \\
\text { binding } \\
\text { protein }\end{array}$ & 1.2687 & 0.0000 & 1.3944 & 0.0000 \\
\hline \multirow[t]{4}{*}{$\begin{array}{l}\text { Secondary } \\
\text { metabolism }\end{array}$} & Solyc03g036470.2 & $\begin{array}{l}\text { Phenylalanine } \\
\text { ammonia- } \\
\text { lyase }\end{array}$ & 6.9354 & 0.0000 & 7.4705 & 0.0000 \\
\hline & Solyc01g101180.3 & $\begin{array}{l}3 \text { Vetispiradiene } \\
\text { synthase } 1\end{array}$ & 6.2134 & 0.0262 & $\mathrm{Nd}$ & $\mathrm{Nd}$ \\
\hline & Solyc03g042560.2 & $\begin{array}{l}2 \text { Phenylalanine } \\
\text { ammonia- } \\
\text { lyase }\end{array}$ & 5.6499 & 0.0000 & 6.0719 & 0.0000 \\
\hline & Solyc08g068640.3 & $\begin{array}{l}\text { Aromatic } \\
\text { amino acid } \\
\text { decarboxy- } \\
\text { lase } \\
\text { 1B }\end{array}$ & $\mathrm{Nd}$ & $\mathrm{Nd}$ & 4.5348 & 0.0014 \\
\hline
\end{tabular}




\begin{tabular}{|c|c|c|c|c|c|c|}
\hline Category & Accession & $\begin{array}{l}\text { Functional } \\
\text { annotation }\end{array}$ & $\begin{array}{l}\log _{2} \text { fold } \\
(\mathrm{OE}-1 / \mathrm{WT})\end{array}$ & padj & $\begin{array}{l}\log _{2} \text { fold } \\
(\mathrm{OE}-6 / \mathrm{WT})\end{array}$ & padj \\
\hline & \multicolumn{3}{|c|}{ Solyc12g019140.2 Polygalacturonase3.8069 } & 0.0000 & $\mathrm{Nd}$ & $\mathrm{Nd}$ \\
\hline & \multicolumn{3}{|c|}{$\begin{array}{r}\text { Solyc03g093620.1 Cytosolic } \\
\text { sulfotrans- } \\
\text { ferase } \\
\text { 5-like }\end{array}$} & 0.0488 & $\mathrm{Nd}$ & $\mathrm{Nd}$ \\
\hline & \multicolumn{3}{|c|}{$\begin{array}{c}\text { Solyc04g083140.2 Premnaspirodiene3.3164 } \\
\text { oxygenase }\end{array}$} & 0.0007 & 2.2807 & 0.0005 \\
\hline & \multicolumn{3}{|c|}{$\begin{array}{l}\text { Solyc07g043710.3 Deacetylvindoline } 2.8057 \\
\text { O- } \\
\text { acetyltransferase- } \\
\text { like }\end{array}$} & 0.0002 & 3.0862 & 0.0003 \\
\hline & \multicolumn{3}{|c|}{$\begin{array}{l}\text { Solyc03g058370.2 Anthocyanidin } 2.5992 \\
\text { 3-O- } \\
\text { glucoside } \\
\text { 5-O- } \\
\text { glucosyltransferase } \\
\text { 1-like }\end{array}$} & 0.0436 & $\mathrm{Nd}$ & $\mathrm{Nd}$ \\
\hline & Solyc03g08: & 3 Pectinesteras & 2.5867 & 0.0149 & $\mathrm{Nd}$ & $\mathrm{Nd}$ \\
\hline & \multicolumn{3}{|c|}{ Solyc08g042010.3 Glycosyltransferas\$d } & $\mathrm{Nd}$ & 2.4170 & 0.0469 \\
\hline & \multicolumn{3}{|c|}{$\begin{aligned} \text { Solyc12g057070.2 } & \text { - } \\
& \text { deoxyloganetin } \\
& \text { glucosyltransferase- } \\
& \text { like }\end{aligned}$} & $\mathrm{Nd}$ & 2.3256 & 0.0373 \\
\hline & Solyc08g074 & $\begin{array}{l}3 \text { Polyphenol } \\
\text { oxidase E }\end{array}$ & 2.1467 & 0.0011 & $\mathrm{Nd}$ & $\mathrm{Nd}$ \\
\hline & Solyc09g06 & $\begin{array}{l}3 \text { Pectate } \\
\text { lyase } 8\end{array}$ & 2.0848 & 0.0096 & $\mathrm{Nd}$ & $\mathrm{Nd}$ \\
\hline & Solyc04g00 & $\begin{array}{l}2 \text { Metalloendop } \\
1\end{array}$ & eih 5.350 & 0.0000 & 1.7948 & 0.0011 \\
\hline & Solyc11g06 & $\begin{array}{l}1 \text { Deacetylvind } \\
\text { O- } \\
\text { acetyltransfer } \\
\text { like }\end{array}$ & e1.7830 & 0.0385 & $\mathrm{Nd}$ & $\mathrm{Nd}$ \\
\hline & Solyc02g06؛ & $\begin{array}{l}3 \text { Phospholipid- } \\
\text { transporting } \\
\text { ATPase } 4\end{array}$ & 1.5364 & 0.0287 & $\mathrm{Nd}$ & $\mathrm{Nd}$ \\
\hline & Solyc02g09 & $\begin{array}{l}1 \text { Cytochrome } \\
\text { P450 }\end{array}$ & $\mathrm{Nd}$ & $\mathrm{Nd}$ & 1.4389 & 0.0434 \\
\hline \multirow[t]{2}{*}{$\begin{array}{l}\text { Protein } \\
\text { degradation }\end{array}$} & Solyc08g067 & $\begin{array}{l}1 \text { F-box only } \\
\text { protein } \\
13 \text {-like }\end{array}$ & 1.1376 & 0.0000 & 1.5751 & 0.0000 \\
\hline & Solyc02g092 & $\begin{array}{l}1 \text { F-box } \\
\text { protein } \\
\text { SKIP2-like }\end{array}$ & 0.8822 & 0.0000 & 1.2939 & 0.0000 \\
\hline
\end{tabular}




\begin{tabular}{|c|c|c|c|c|c|c|}
\hline Category & Accession & $\begin{array}{l}\text { Functional } \\
\text { annotation }\end{array}$ & $\begin{array}{l}\log _{2} \text { fold } \\
(\mathrm{OE}-1 / \mathrm{WT})\end{array}$ & padj & $\begin{array}{l}\log _{2} \text { fold } \\
(\mathrm{OE}-6 / \mathrm{WT})\end{array}$ & padj \\
\hline & \multicolumn{2}{|c|}{$\begin{aligned} & \text { Solyc01g007025.1 } \text { E3 } \\
& \text { ubiquitin- } \text { protein } \\
& \text { ligase } \\
& \text { PUB22-like }\end{aligned}$} & $\mathrm{Nd}$ & $\mathrm{Nd}$ & 2.3375 & 0.0072 \\
\hline & \multicolumn{2}{|c|}{$\begin{aligned} \text { Solyc01g007040.3 E3 } & \\
& \text { ubiquitin- } \\
\text { protein } & \text { ligase } \\
& \text { PUB22-like }\end{aligned}$} & 1.5487 & 0.0000 & 1.8922 & 0.0000 \\
\hline & \multicolumn{2}{|c|}{$\begin{array}{l}\text { Solyc01g007020.3 } \mathrm{E} 3 \\
\text { ubiquitin- } \\
\text { protein } \\
\text { ligase } \\
\text { PUB23-like }\end{array}$} & 1.4994 & 0.0000 & 1.7981 & 0.0000 \\
\hline & \multicolumn{2}{|c|}{$\begin{array}{r}\text { Solyc01g007030.3 E3 } \\
\text { ubiquitin- } \\
\text { protein } \\
\text { ligase } \\
\text { PUB22-like }\end{array}$} & 1.3272 & 0.0000 & 1.5034 & 0.0000 \\
\hline & \multicolumn{2}{|c|}{$\begin{aligned} & \text { Solyc12g055710.1 } \text { RING-H2 } \\
& \text { finger } \\
& \text { protein } \\
& \text { ATL3-like }\end{aligned}$} & 1.7064 & 0.0278 & 2.0840 & 0.0009 \\
\hline & \multicolumn{2}{|c|}{$\begin{aligned} & \text { Solyc06g053640.1 } \text { RING-H2 } \\
& \text { finger } \\
& \text { protein } \\
& \text { ATL16-like }\end{aligned}$} & 1.6536 & 0.0000 & 1.7403 & 0.0000 \\
\hline & \multicolumn{2}{|c|}{$\begin{aligned} & \text { Solyc03g083480.3 RING-H2 } \\
& \text { finger } \\
& \text { protein } \\
& \text { ATL21A }\end{aligned}$} & 1.0665 & 0.0023 & 1.4985 & 0.0000 \\
\hline \multirow[t]{2}{*}{ Methylation } & \multicolumn{3}{|c|}{$\begin{array}{c}\text { Solyc03g026120.3 Methyltransferase1.4905 } \\
\text { PMT16 }\end{array}$} & 0.0054 & $\mathrm{Nd}$ & $\mathrm{Nd}$ \\
\hline & \multicolumn{2}{|c|}{$\begin{array}{l}\text { Solyc05g054240.3 Histone- } \\
\text { arginine } \\
\text { methyltrans- } \\
\text { ferase } \\
1.3\end{array}$} & 1.7949 & 0.0001 & 2.3216 & 0.0000 \\
\hline Kinases & \multicolumn{2}{|c|}{$\begin{aligned} \text { Solyc07g006480.3 } & \text { Inactive } \\
& \text { leucine-rich } \\
& \text { repeat } \\
& \text { receptor-like } \\
\text { protein } & \text { kinase }\end{aligned}$} & 3.6759 & 0.0213 & $\mathrm{Nd}$ & $\mathrm{Nd}$ \\
\hline
\end{tabular}




\begin{tabular}{|c|c|c|c|c|c|c|}
\hline Category & Accession & $\begin{array}{l}\text { Functional } \\
\text { annotation }\end{array}$ & $\begin{array}{l}\log _{2} \text { fold } \\
(\mathrm{OE}-1 / \mathrm{WT})\end{array}$ & padj & $\begin{array}{l}\log _{2} \text { fold } \\
(\mathrm{OE}-6 / \mathrm{WT})\end{array}$ & padj \\
\hline & \multicolumn{3}{|c|}{$\begin{array}{c}\text { Solyc11g020230.1 } \\
\text { Serine/threonine- } 1.6912 \\
\text { protein } \\
\text { kinase-like } \\
\text { protein } \\
\text { CCR4 }\end{array}$} & 0.0000 & 2.2653 & 0.0000 \\
\hline & \multicolumn{3}{|c|}{ 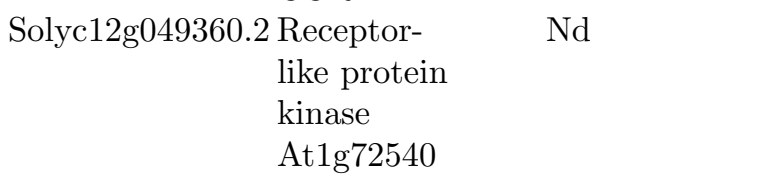 } & $\mathrm{Nd}$ & 2.0361 & 0.0254 \\
\hline & \multicolumn{3}{|c|}{$\begin{array}{l}\text { Solyc02g064980.1 } \\
\text { Mitogen- } \\
\text { activated } \\
\text { protein } \\
\text { kinase } \\
\text { kinase } \\
\text { kinase 1-like }\end{array}$} & $\mathrm{Nd}$ & 1.8545 & 0.0000 \\
\hline & \multicolumn{2}{|c|}{$\begin{aligned} & \text { Solyc08g066310.2 } \text { Receptor- } \\
& \text { like protein } \\
& \text { kinase } 2\end{aligned}$} & 1.6095 & 0.0195 & $\mathrm{Nd}$ & $\mathrm{Nd}$ \\
\hline & \multicolumn{2}{|c|}{$\begin{array}{l}\text { Solyc07g064820.1 Mitogen- } \\
\text { activated } \\
\text { protein } \\
\text { kinase } \\
\text { kinase } \\
\text { kinase 2-like }\end{array}$} & 1.3676 & 0.0000 & 1.6031 & 0.0000 \\
\hline & \multicolumn{2}{|c|}{$\begin{array}{r}\text { Solyc11g006040.2 Receptor } \\
\text { protein } \\
\text { kinase } \\
\text { TMK1 } \\
\end{array}$} & 1.4171 & 0.0018 & $\mathrm{Nd}$ & $\mathrm{Nd}$ \\
\hline
\end{tabular}




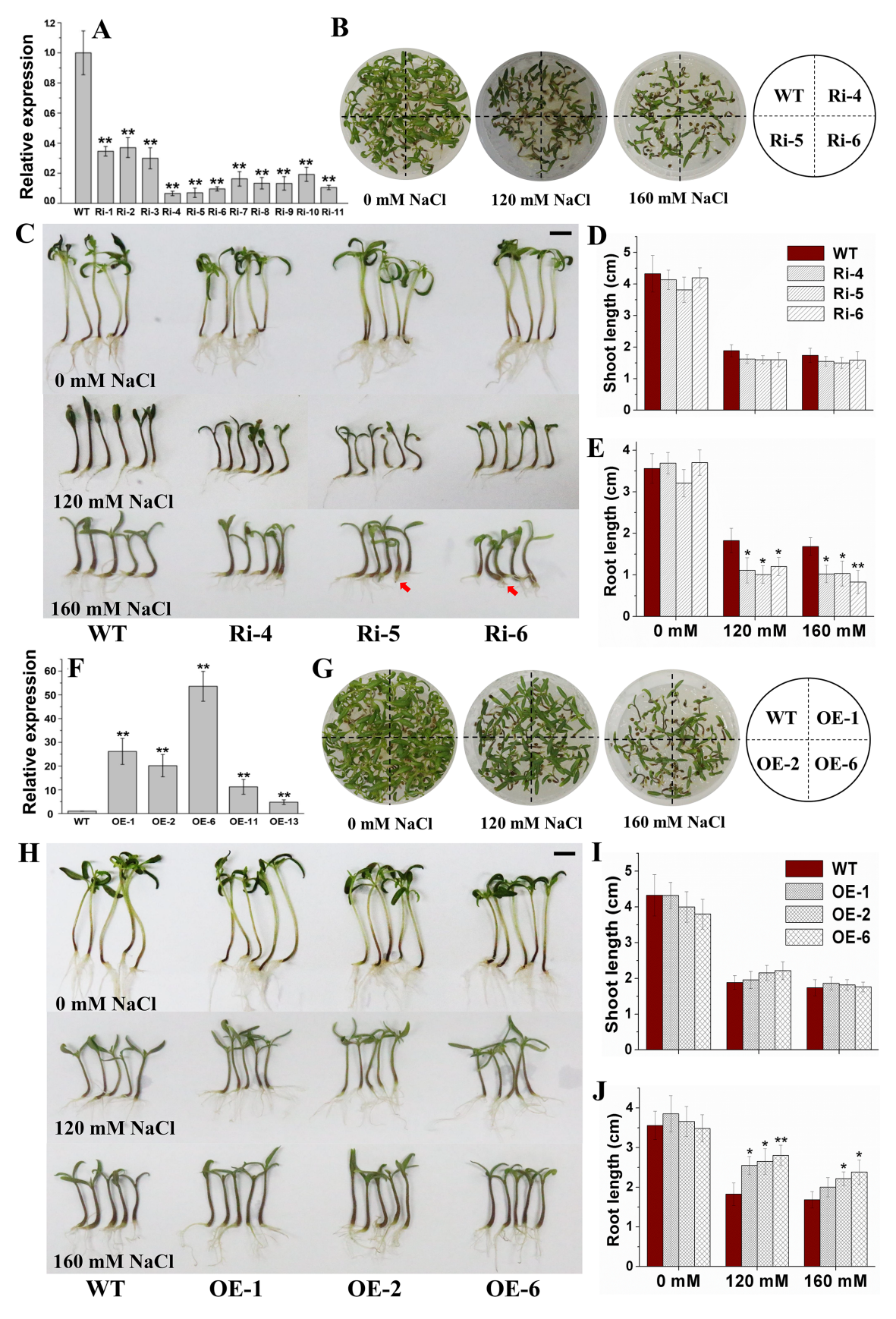



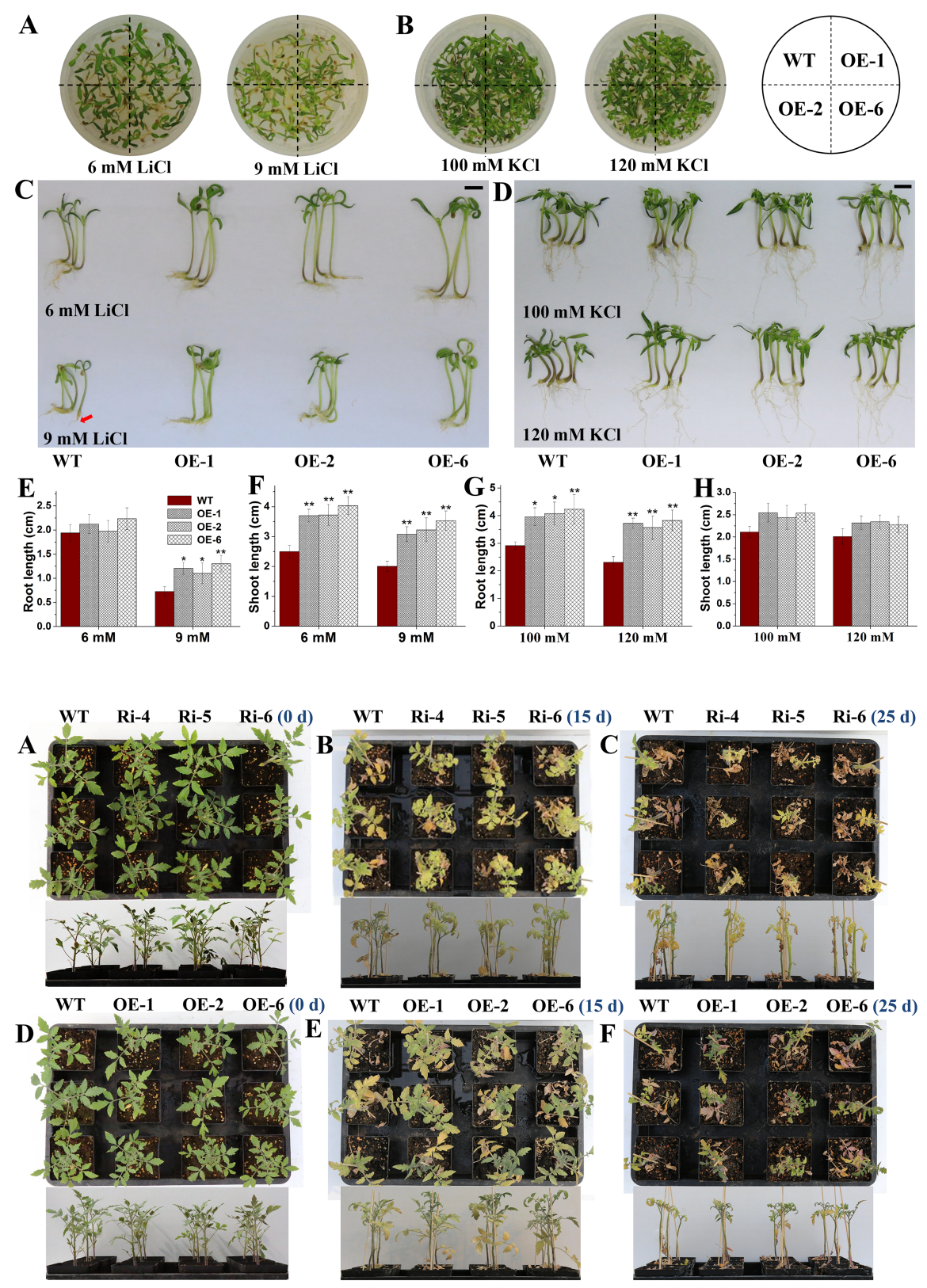

$\mathbf{G}^{80}$
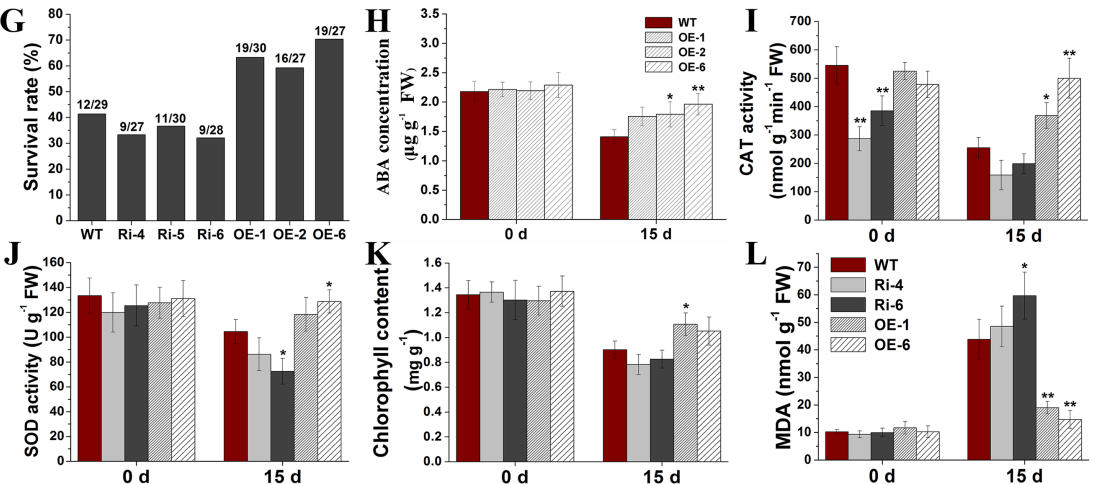

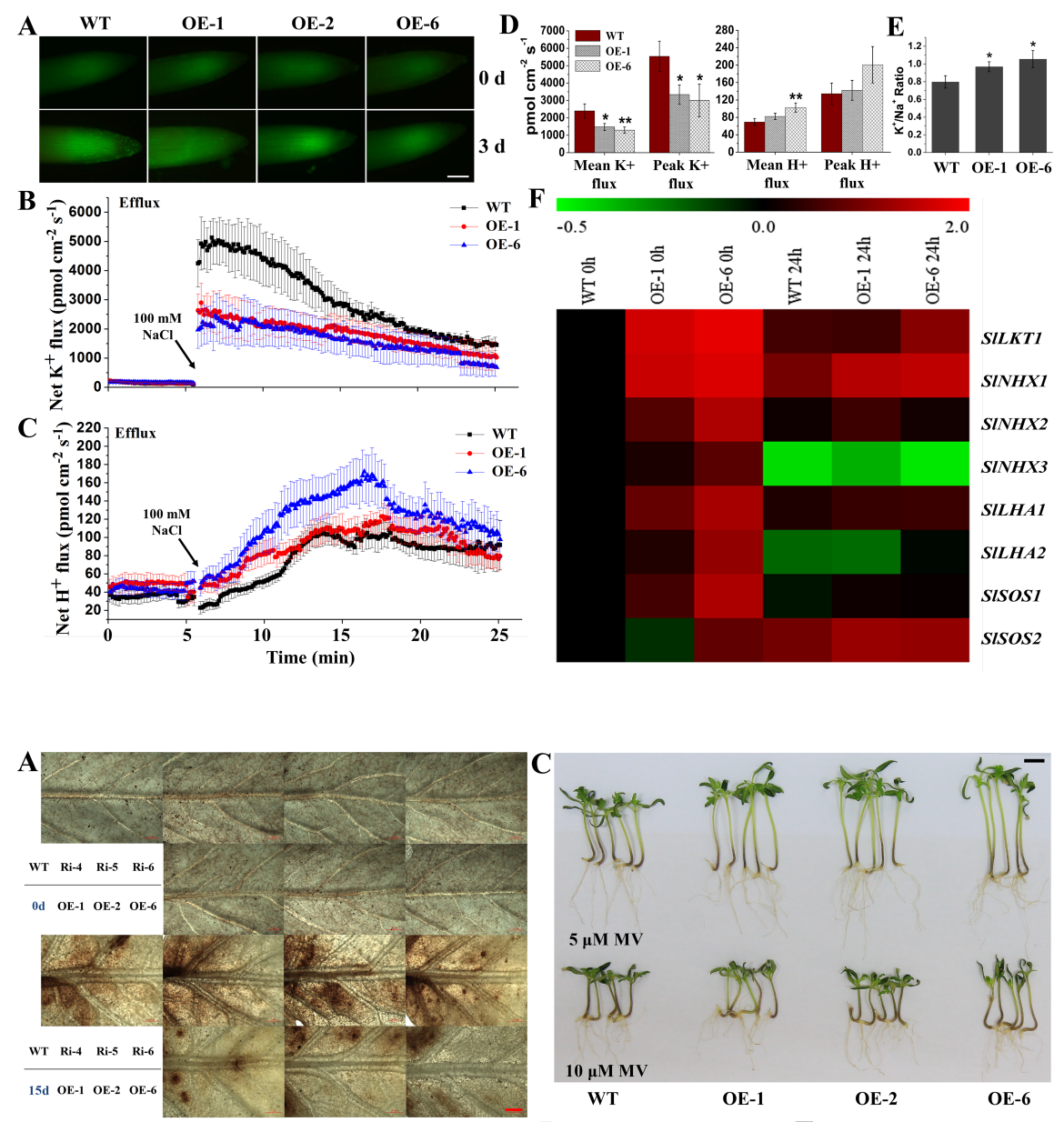

B

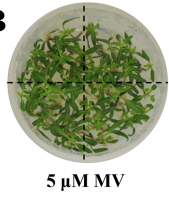

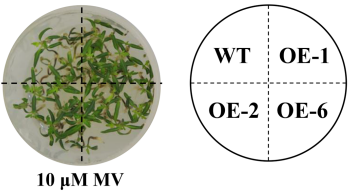

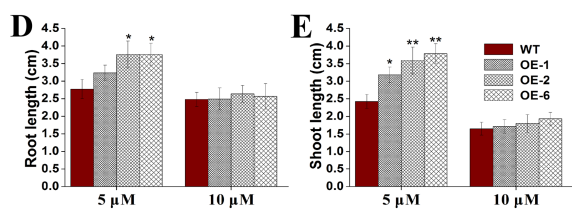


A
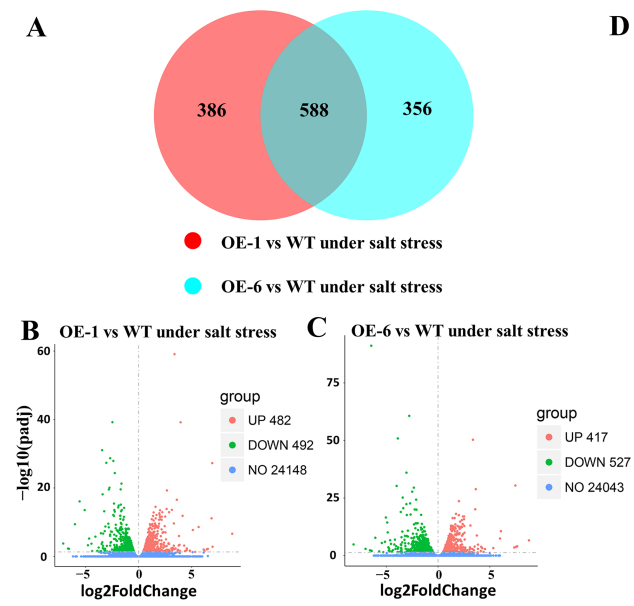

E

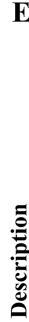

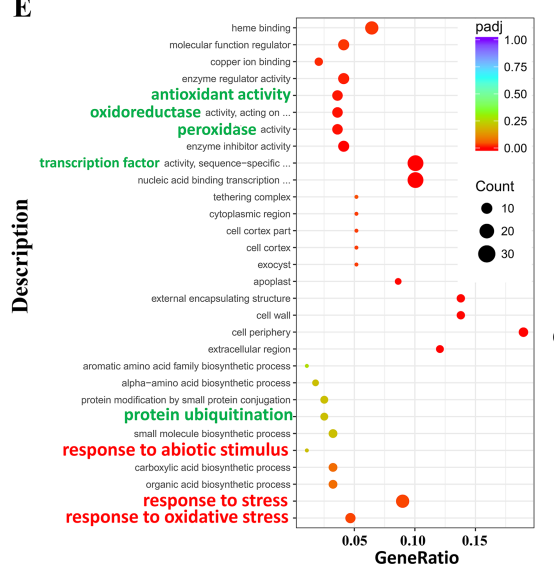

D
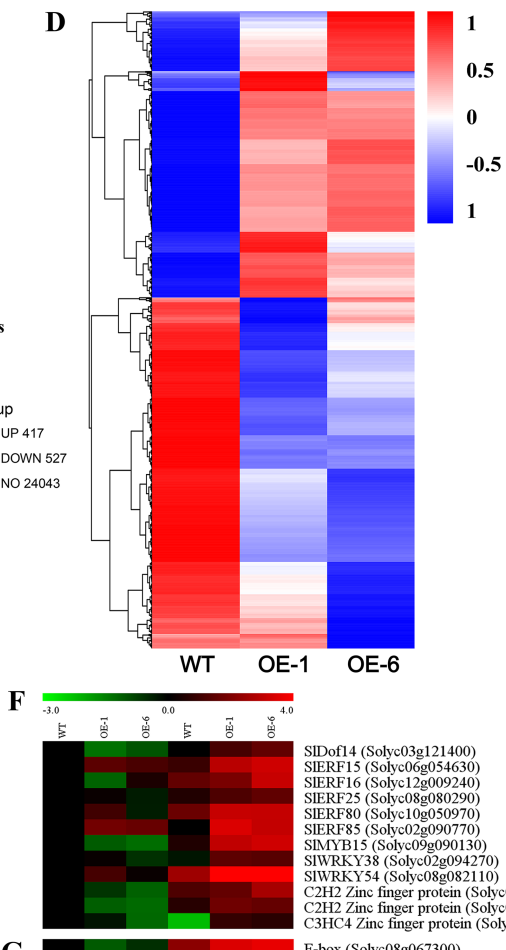

SIDof14 (Solyc03g121400)

SIERF16 (Solyc120009240
SIERF25 (Solyc080080290)

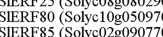

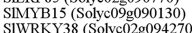

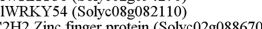

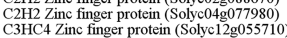

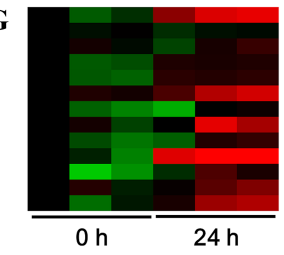

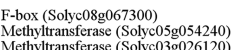

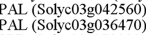

Proline dehydrogenase (Solyc020089630)

RLK (Solyc0770006480)

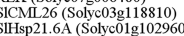

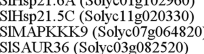

$0 \mathrm{~h} \quad 24 \mathrm{~h}$
A
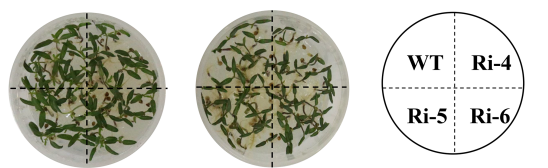

B
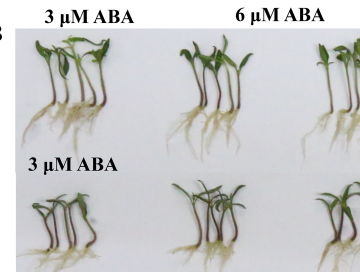

$6 \mu \mathrm{M} \mathrm{ABA}$

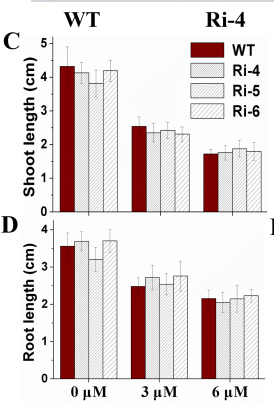

Ri-4
WT

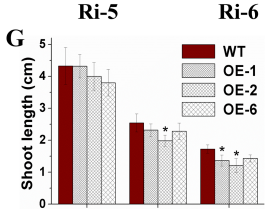

H
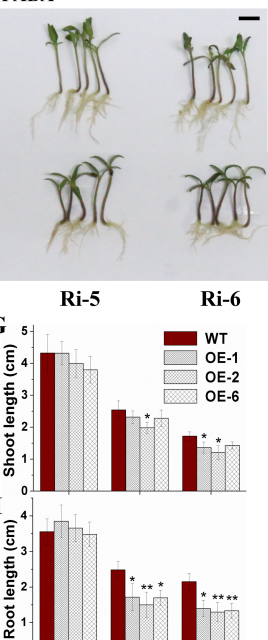
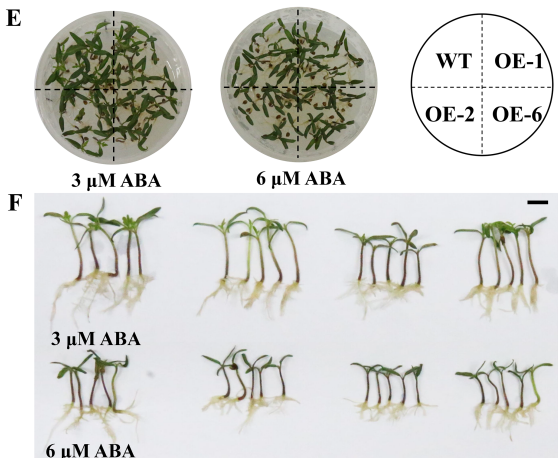

$6 \mu \mathrm{M} \mathrm{ABA}$
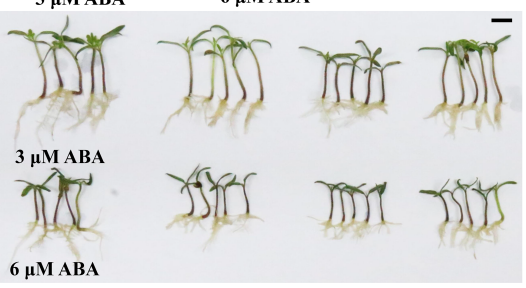

WT

OE-1

OE-2

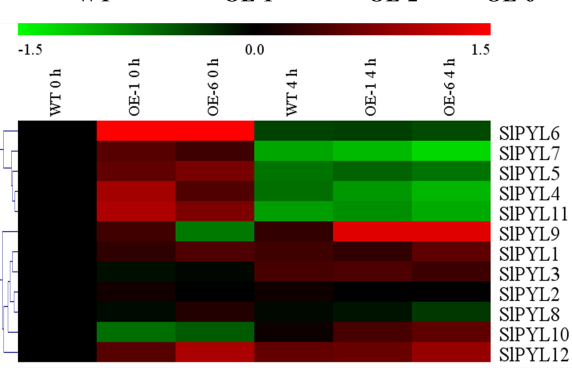




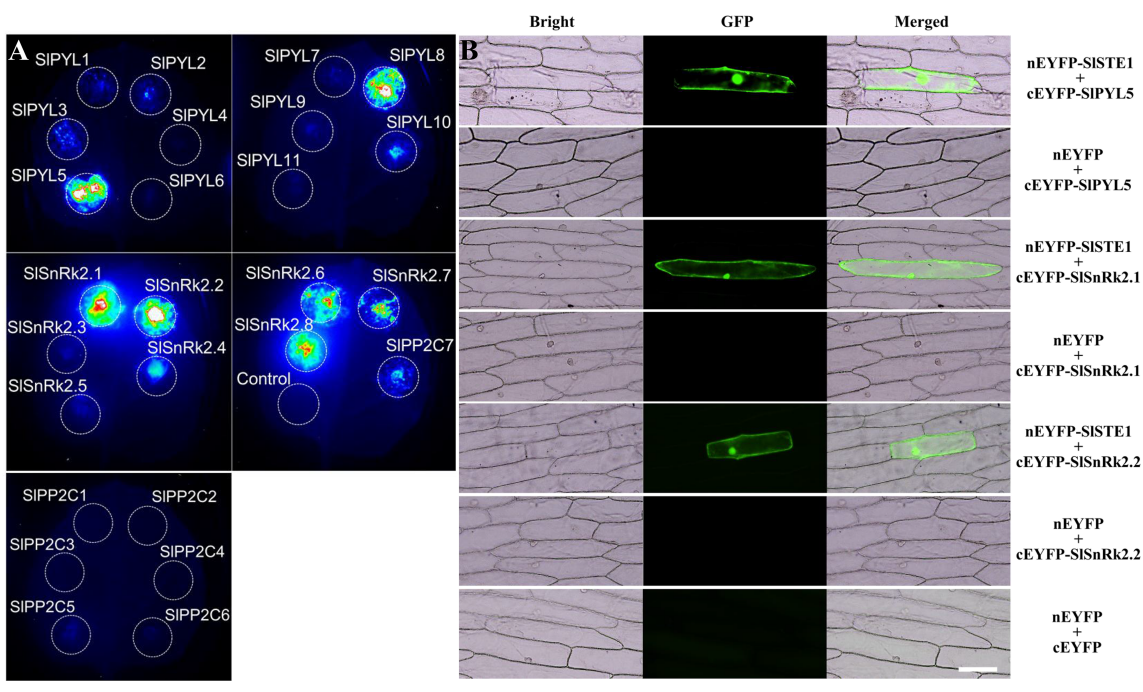

